\title{
Dying cell clearance and its impact on the outcome of tumor radiotherapy
}

\author{
Kirsten Lauber ${ }^{1}$ *, Anne Ernst ${ }^{1}$, Michael Orth ${ }^{1}$, Martin Herrmann ${ }^{2}$ and Claus Belka ${ }^{1}$ \\ ' Department of Radiotherapy and Radiation Oncology, Ludwig Maximilian University of Munich, Munich, Germany \\ ${ }^{2}$ Department of Internal Medicine 3, Friedrich-Alexander-Universität Erlangen-Nürnberg, Erlangen, Germany
}

\section{Edited by:}

Udo S. Gaipl, University Hospital

Erlangen, Germany

\section{Reviewed by:}

Patrizia Rovere Querini, Fondazione

Centro San Raffaele del Monte Tabor and Vita-Salute University, Italy

lan Dransfield, University of

Edinburgh, UK

\section{*Correspondence:}

Kirsten Lauber, Department of Radiotherapy and Radiation Oncology, Ludwig Maximilian University of

Munich, Munich, Germany.

e-mail: kirsten.lauber@med.uni-

muenchen.de
The induction of tumor cell death is one of the major goals of radiotherapy and has been considered to be the central determinant of its therapeutic outcome for a long time. However, accumulating evidence suggests that the success of radiotherapy does not only derive from direct cytotoxic effects on the tumor cells alone, but instead might also depend - at least in part - on innate as well as adaptive immune responses, which can particularly target tumor cells that survive local irradiation. The clearance of dying tumor cells by phagocytic cells of the innate immune system represents a crucial step in this scenario. Dendritic cells and macrophages, which engulf, process and present dying tumor cell material to adaptive immune cells, can trigger, skew, or inhibit adaptive immune responses, respectively. In this review we summarize the current knowledge of different forms of cell death induced by ionizing radiation, the multi-step process of dying cell clearance, and its immunological consequences with special regard toward the potential exploitation of these mechanisms for the improvement of tumor radiotherapy.

Keywords: Radiotherapy, apoptosis, necrosis, necroptosis, senescence, mitotic catastrophe, dying cell clearance
Radiotherapy is an essential treatment option for various types of cancer due to its profound potential to kill malignant cells and to abrogate clonogenic survival. Ionizing radiation, including X-rays, gamma rays, and heavy ions, induces damages in the cellular DNA, which lead to the activation of a highly sophisticated and finely tuned signaling cascade designated the DNA damage response (DDR) and - depending on the extent of damage - to transient or permanent cell cycle arrest, and/or cell death, respectively.

\section{THE DNA DAMAGE RESPONSE}

The DDR is orchestrated by two conserved protein kinases, ATM (ataxia telangiectasia, mutated) and ATR (ATM and Rad3 related), which in concert control the cellular response to DNA double strand breaks (DSBs) and single-stranded (ss) DNA (Smith et al., 2010). ATM is recruited to DSBs by the Mre11-Rad50Nbs1 (MRN) complex and phosphorylates the histone $\mathrm{H} 2$ variant $\mathrm{H} 2 \mathrm{AX}$, thus generating an interaction platform for other DDR constituents required for DSB repair (Shiloh, 2006). Concomitantly, ATM activates the DNA damage checkpoint by initiating the resection of the broken strand(s) leading to the generation of ssDNA, a DNA damage repair intermediate which, in turn, activates ATR kinase (Hurley and Bunz, 2007). ATR and ATM phosphorylate and activate two respective effector kinases termed Chk1 and Chk2. Collectively, these four protein kinases instigate multiple cellular pathways culminating in transient or permanent cell cycle arrest, DNA damage repair, and/or cell death (Jackson and Bartek, 2009). A crucial target of the ATM/ATR cascade is the tumor suppressor protein p53, a transcription factor, whose function is lost or compromised in more than $50 \%$ of all cancers (Levine, 1997). Under steady-state conditions, p53 protein is sustained at very low levels, since it is continuously being ubiquitinylated by the Mdm2 ubiquitin ligase and thus targeted for subsequent proteolytic degradation via the $26 \mathrm{~S}$ proteasome. Yet, phosphorylation of $\mathrm{p} 53$ by kinases of the ATM/ATR pathway induces the dissociation of p53 from MDM2, and the subsequent reduction in $\mathrm{p} 53$ ubiquitinylation leads to a deceleration of proteasome-mediated degradation and hence a stabilization of p53 (Meek, 2009). Depending on the cell cycle phase and the type as well as the extent of DNA damage, p53 can function as a modulator of the DNA damage repair process, or as a transcriptional activator of genes, which are involved in transient or permanent cell cycle arrest, and/or cell death, respectively (Sengupta and Harris, 2005).

\section{APOPTOSIS}

Apoptosis is one type of programed cell death. It is commonly considered to be the prevalent form of cell death underlying daily tissue regeneration and renewal. Morphologically, it is characterized by cellular shrinkage, chromatin condensation, nuclear fragmentation, and membrane blebbing (Figure 1). In response to radiotherapy, apoptosis is predominantly observed in cells of the hematopoietic system, and it is critically regulated by the mitochondrial, intrinsic death pathway (Rudner et al., 2001; Eriksson and Stigbrand, 2010). The pivotal events in this context involve the permeabilization of the mitochondrial outer membrane (MOMP) and the release of various proteins, including cytochrome $c$, from the mitochondrial intermembrane space into the cytosol, thus stimulating the formation of the apoptosome and the activation of procaspase-9. Activated caspase-9, in turn, triggers the activation of downstream effector caspases, which execute the final stages of apoptosis and the disintegration of the cell (Taylor et al., 2008). Crucial regulators of 


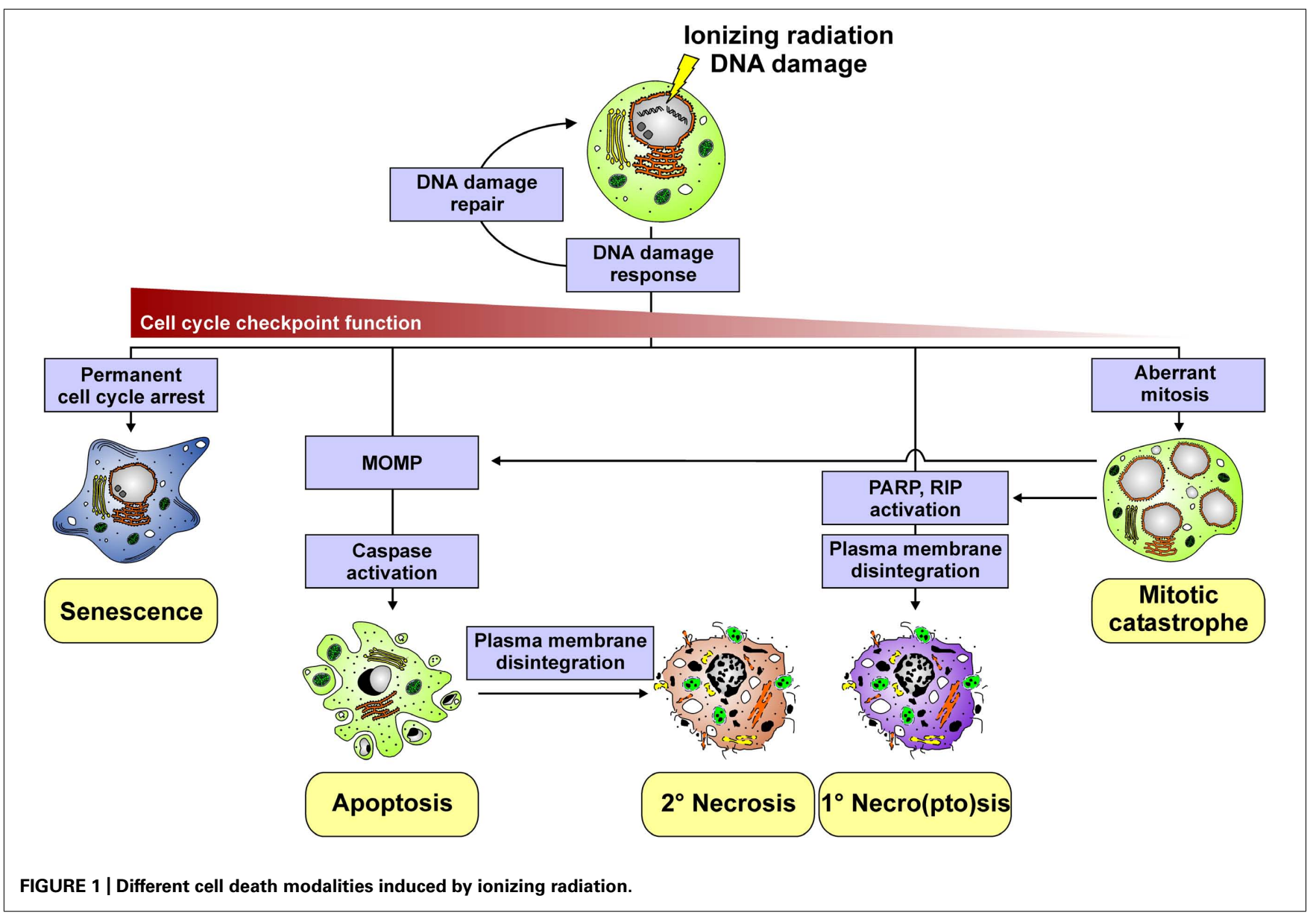

mitochondrial permeabilization and cytochrome $c$ release are proteins of the B cell lymphoma-2 (Bcl-2) family, including the pro-apoptotic BH3-only (e.g., Puma) and the anti-apoptotic (e.g., Bcl-2) family members, which control MOMP via their impact on the oligomerization of the effector members Bax and Bak (Youle and Strasser, 2008). p53 links this signaling pathway to radiation-induced DNA damage by transactivating the expression of pro-apoptotic Bcl-2 family members, such as Puma and Noxa (Sengupta and Harris, 2005). Apart from the intrinsic pathway, apoptosis can be induced extrinsically via the ligation of death receptors, such as CD95 or the TRAIL receptors 1 and 2, by their corresponding ligands (Debatin and Krammer, 2004). Receptor clustering leads to recruitment and activation of the pro-caspases- 8 and -10, triggering of the caspase cascade, and thus to apoptosis. Various proteins of the death receptor pathway are known to be upregulated in response to ionizing radiation (p53-dependently as well as -independently) and thus might contribute to apoptosis induction (Belka et al., 1998; Haupt et al., 2003). However, the intrinsic death pathway appears to be the major signaling mechanism of irradiationinduced apoptosis (Rudner et al., 2001). Notably, although p53 essentially controls the expression of various key regulators of apoptosis, irradiation-induced apoptosis can be observed in cancer cells with defective p53 function. Here, mechanisms, such as p63-/p73-dependent induction of pro-apoptotic Bcl-2 members and p53-independent stimulation of death receptor signaling have been described to be involved (Afshar et al., 2006; Wakatsuki et al., 2008).

\section{NECROPTOSIS AND NECROSIS}

In tumor cells of epithelial origin, which reveal limited apoptosis induction in response to radiotherapy, radiation-induced DNA damage - especially when combined with hyperthermia has been reported to stimulate necroptosis (Mantel et al., 2010; Schildkopf et al., 2010; Figure 1). The crucial events in this context include the hyperactivation of the DNA repair enzyme poly-ADPribose-polymerase (PARP) and the subsequent and substantial depletion of intracellular ATP levels (Vandenabeele et al., 2010; Vanlangenakker et al., 2012). This - in a so far poorly understood way - couples to the activation of receptor interacting protein (RIP), the formation of the high-molecular weight necrosome, and finally the execution of necroptosis as characterized by the production of reactive oxygen species (ROS), lipid peroxidation, swelling of organelles, rupture of the plasma membrane, and release of intracellular contents (Vandenabeele et al., 2010). Apart from necroptosis, ionizing radiation - particularly when applied in high single doses during ablative radiotherapy - can trigger necrosis, an accidental, uncontrolled form of cell death as a consequence of excessive physico-chemical stress (Vandenabeele et al., 2010). Moreover, secondary necrosis can occur when apoptotically 
dying cells are not properly and timely engulfed by neighboring cells or professional phagocytes, respectively (Munoz et al., 2010a; Silva, 2010). This is of specific relevance when the local phagocytic compartment is overwhelmed due to massive apoptosis induction in the context of tumor radiotherapy. In both cases the integrity of the plasma membrane is lost and cellular contents, often in an oxidatively modified and partially degraded form, leak into the surrounding tissue.

\section{MITOTIC CATASTROPHE}

Mitotic catastrophe is a form of cell stress, which occurs in the context or as a result of aberrant mitosis owing to uncoordinated or improper entry into mitosis. It has been assigned to be the major death mechanism in response to irradiation-induced DNA damage of cells with defects in cell cycle checkpoints and impaired DNA repair mechanisms (e.g., cells with defective p53). In the course of mitotic catastrophe the formation of giant cells can be observed with aberrant nuclear morphology, centrosome hyperamplification, and multiple nuclei, and/or several micronuclei (Figure 1). These cells may survive for days, transit into senescence, or die by delayed apoptosis or delayed necro(pto)sis, respectively (Eriksson and Stigbrand, 2010).

\section{SENESCENCE}

Radiation-induced senescence is a condition of permanent cell cycle arrest, which can be observed in cells, where DNA damage is excessive and cell cycle checkpoints are still intact (Figure 1). The hallmarks of cellular senescence include an enlarged and flattened cellular morphology, increased granularity, upregulation of cyclin-dependent kinase inhibitors, such as $\mathrm{p} 16^{\mathrm{INK} 4 \mathrm{a}}, \mathrm{p} 21^{\text {Waf1 }}$, and $\mathrm{p} 27^{\mathrm{Kip} 1}$, and positive staining for the senescence-associated $\beta$-galactosidase (SA- $\beta$-Gal). The key players in this scenario are p53 and pRB, yet senescent phenotypes have also been reported in the absence of functional p53 (Nardella et al., 2011). Senescent cells exit the cell cycle and do not further undergo cell division, but may remain metabolically active. Interestingly, they have been shown to release factors, which can be tumor suppressing as well as tumor promoting, and which can alter the immune response (Kuilman and Peeper, 2009; Coppe et al., 2010).

\section{DYING CELL CLEARANCE}

Higher organisms have developed impressively efficient mechanisms of dying cell clearance as can be appreciated from the fact that dying cells are rarely to be observed in normal tissues, although - according to careful estimations - approximately one million cells per second undergo apoptosis in the course of everyday tissue turnover and regeneration (Reed, 2006). These cells are swiftly phagocytosed and degraded, and the immune system had to acquire the capability to distinguish them from cells, which are dying in the context of an infection. Whereas several types of amateur phagocytes, including fibroblasts, endothelial cells, and mesothelial cells, have been described, professional phagocytes, such as macrophages and dendritic cells (DCs), apparently play a crucial role in this scenario, particularly when the local amateur phagocytic compartment is overwhelmed (Lauber et al., 2004; Ravichandran, 2011; Wagner et al., 2011). Macrophages and DCs serve as professional dying cell scavengers with discrepant tasks. While tissue resident macrophages can proficiently engulf and degrade huge amounts of dying prey cells, DCs act as sentinels, which are highly potent in presenting and cross-presenting antigens, thus stimulating, skewing, or inhibiting adaptive immune responses, respectively (Steinman, 2007; Biswas and Mantovani, 2010).

The sophisticated process of dying cell removal involves distinct phases: phagocyte recruitment, prey cell engulfment, and the postphagocytic response (Ravichandran, 2010; Figure 2).

\section{PHAGOCYTE RECRUITMENT}

Phagocyte recruitment is accomplished by the release of soluble "find-me" signals from the dying cell (Munoz et al., 2010b; Peter etal., 2010; Figure 3). In case of apoptotic cells, these "find-me" signals comprise different molecular entities. As such, nucleotides, like ATP and UTP, have been described to trigger monocyte/macrophage recruitment via the purinergic $\mathrm{P}_{2} \mathrm{Y}_{2}$ receptor (Elliott et al., 2009). Released proteins, including a covalently linked dimer of ribosomal protein S19 (dRPS19), endothelial monocyte activating polypeptide II (EMAP-II), soluble fractalkine (sFKN), and the ectodomain of the IL-6 receptor (sIL-6R) also contribute to phagocyte attraction and involve their cognate receptors CD88, CXCR3, CX 3 CR1, and CD130 (Nishiura etal., 1998; Hou etal., 2006; Chalaris et al., 2007; Truman et al., 2008). Phospholipids, such as lysophosphatidylcholine (LPC) and sphingosine-1-phosphate (S1P), complement the molecular spectrum of apoptotic cell-derived "find-me" signals and have been reported to stimulate monocyte/macrophage chemotaxis via the G-protein coupled receptor G2A or the family of the S1P receptors (S1PR1-5), respectively (Lauber et al., 2003; Gude etal., 2008; Peter et al., 2008). Finally, also microblebs carrying ICAM-3 have been assigned a role in phagocyte recruitment by apoptotic cells (Segundo et al., 1999; Torr et al., 2012). Amongst the mediators being liberated during apoptosis, lactoferrin (LTF) plays a special role. Its de novo expression and release by apoptotic cells have been described, but in contrast to the "find-me" signals described above, LTF exerts the function of a granulocytic anti-attraction or "keep-out" signal, since it exerts a deterring effect on neutrophils and eosinophils and prevents them from invading the area of apoptotic cell death (Bournazou et al., 2009).

Of note, all these factors are released and/or secreted while the plasma membrane is still intact - a crucial hallmark of bona fide apoptosis, which fundamentally discriminates it from necro(pto)sis. In the course of the latter, the disintegration of the plasma membrane liberates the intracellular contents, and the most abundant factors within this "releasate" act as endogenous danger signals or damage-associated molecular patterns (DAMPs) that "inform" the immune system about the tissue damage (Matzinger, 1998; Lotze et al., 2007). The majority of danger signals have been reported to exert pleiotropic effects on the immune system, with phagocyte recruitment being one of them. As such, high mobility group box 1 protein (HMGB-1) and its close relative hepatoma-derived growth factor (HDGF), peroxiredoxins (Prx), members of the S100 protein family, and heat shock proteins (HSPs) can stimulate monocyte/macrophage attraction by engaging the Toll-like receptors 2 and 4 (TLR2/4), the receptor 


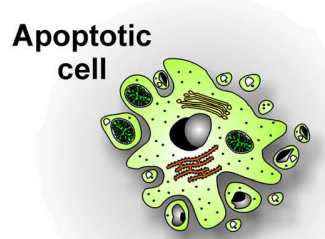

Phagocyte

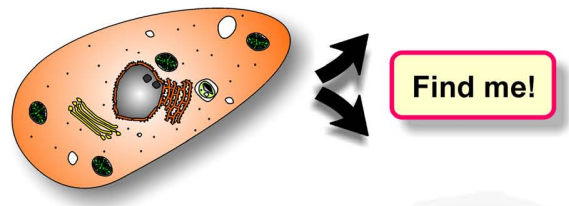

Necro(pto)tic cell

Senescent

cell

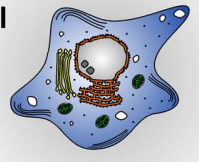

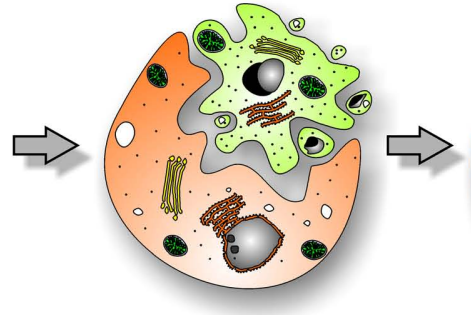

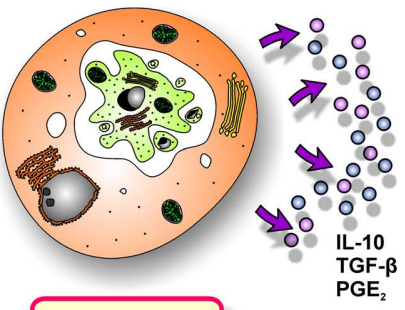

Tolerate me!
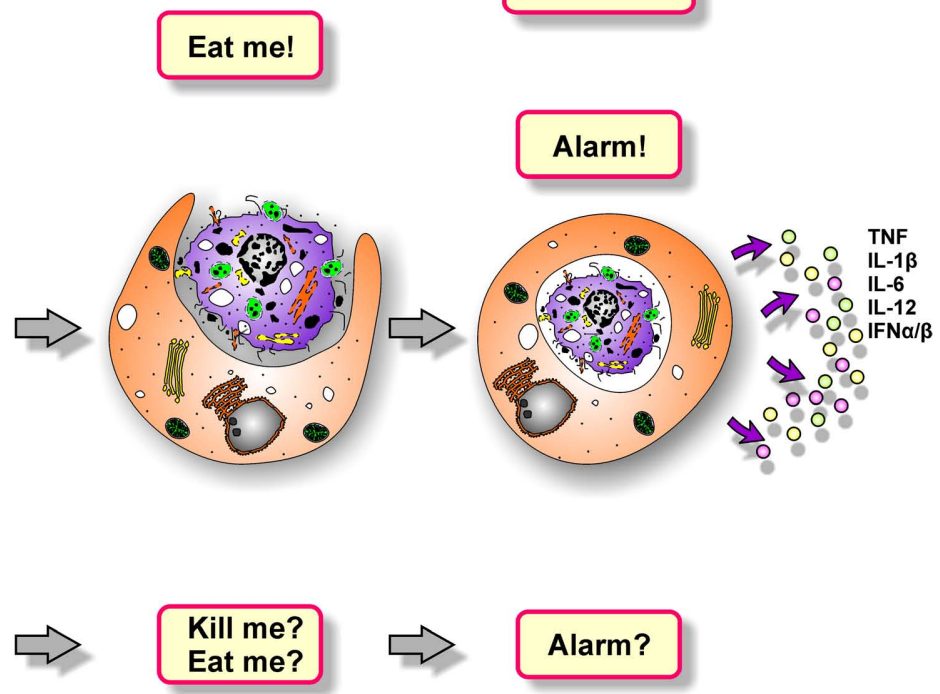

FIGURE 2 | The multi-step process of dying cell clearance.

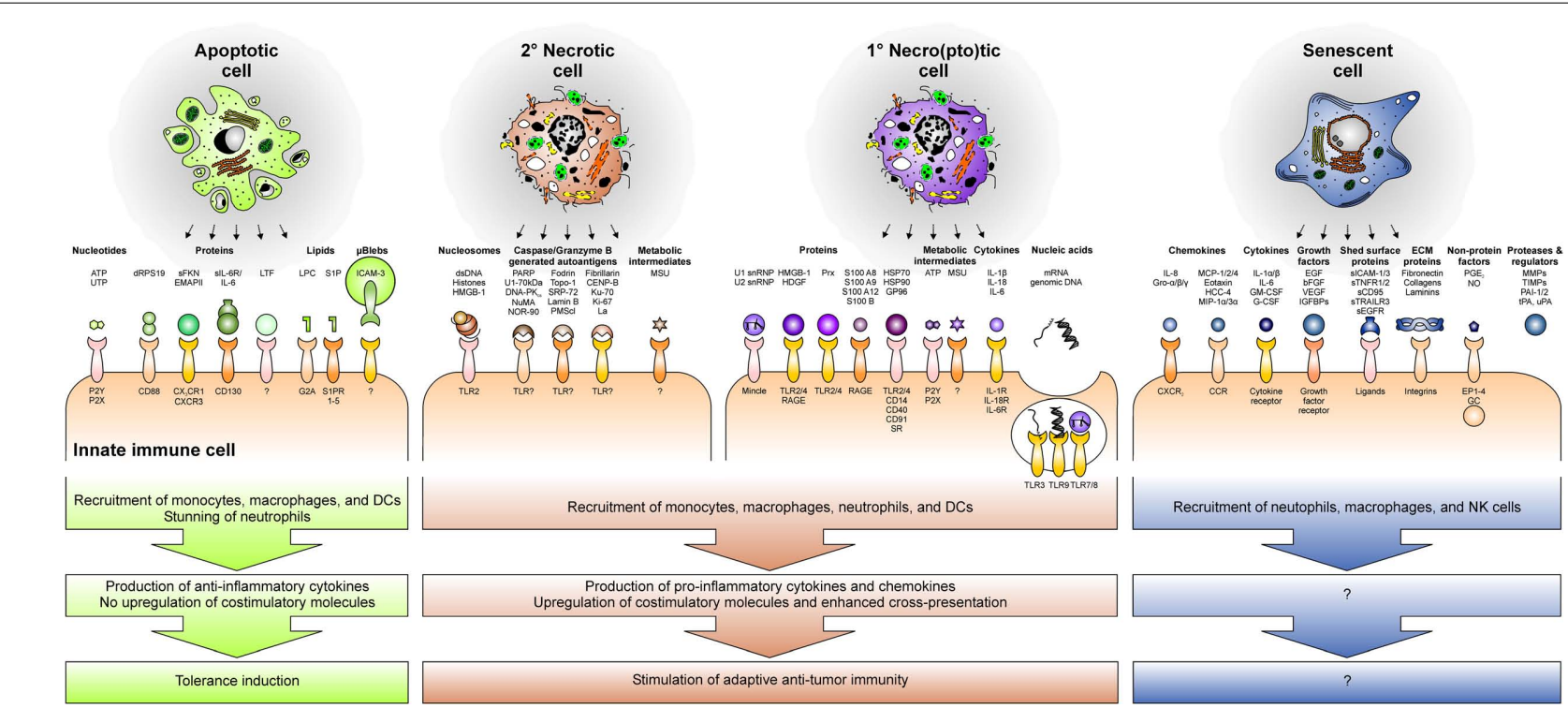

FIGURE 3 |The secretome and releasate of cells undergoing different forms of cell death and senescence recruit immune cells and skew the immune response toward tolerance induction or anti-tumor immunity. 
for advanced glycation end products (RAGE), and members of the scavenger receptor (SR) family (Eue et al., 2000; Bianchi and Manfredi, 2007; Tsan and Gao, 2009; Shichita et al., 2012). Additionally, ATP and uric acid, which readily forms monosodium urate (MSU) crystals in the extracellular space, have been assigned a phagocyte attracting danger signal function. Yet, the receptor for MSU crystals, if there is any, remains to be identified (Shi et al., 2010).

In case of post-apoptotic, secondary necrotic cells, the process of phagocyte recruitment is only poorly understood. One could argue that the repertoire of soluble mediators released by secondary necrotic cells should be a sum of the factors released by apoptotic and primary necro(pto)tic cells. However, it has to be taken into account that dRP S19, EMAP-II, sFKN, sIL-6R, LPC, S1P, and micro-blebs are released early during apoptosis, and according to the ubiquitous presence of degrading enzymes in the extracellular space the stability of these compounds is presumably rather limited. Hence, it is questionable if these mediators are still present and active after the transition into secondary necrosis. Moreover, the factors liberated during primary and secondary necrosis should differ essentially, since the key danger signals described in the context of primary necrosis undergo modifications during apoptosis: ATP is consumed and intracellular proteins are proteolytically processed, which might enhance as well as abolish their danger signal function (Galluzzi et al., 2012). Yet, available data on this issue are limited. From the present point of view, the most likely candidates for secondary necrotic cell-derived "find-me" signals are MSU crystals, since the amount of releasable uric acid - owing to the degradation of chromatin - supposedly is even higher than in the case of primary necrosis, and HMGB-1 associated with secondary necrotic cell-derived nucleosomes (Urbonaviciute et al., 2008; Shi et al., 2010). In addition, annexin A1 has very recently been shown to translocate to the outer leaflet of the plasma membrane and to be proteolytically processed into a peptide, which subsequently is released and stimulates monocytes/ macrophage chemotaxis during secondary necrosis (Blume et al., 2009, 2012).

\section{DYING CELL ENGULFMENT}

When phagocytes reach the dying cells, they identify and recognize their prey by "eat-me" signals, which are exposed on the cell surface. For apoptotic cells, the dominant "eat-me" signal appears to be phosphatidylserine (PS), an anionic phospholipid that during apoptosis translocates from the inner to the outer leaflet of the plasma membrane (Fadok etal., 1992; Krahling et al., 1999). PS is recognized directly by specific PS receptors, including brain angiogenesis inhibitor 1 (BAI-1), members of the $\mathrm{T}$ cell Ig and mucin family (TIM-1, -3 , and -4), and the stabilins 1 and 2 (Kobayashi et al., 2007; Miyanishi et al., 2007; Park et al., 2007, 2008, 2009; Nakayama et al., 2009). Additionally, PS can be recognized indirectly via the mediation of soluble bridging proteins. They link PS to different engulfment receptors of the phagocyte, and originate from the phagocyte, the dying cell, or the interstitial body fluids, respectively. Milk fat globule EGF factor 8 (MFG-E8) and its close relative developmental endothelial locus 1 (Del-1) are examples for phagocyte-derived bridging proteins and ligate PS to $\alpha_{\nu} \beta_{3 / 5}$ integrins (Hanayama et al., 2002). In addition, annexin A1 can be released by the phagocyte for apoptotic cell opsonization, but it has also been reported to be the prototypical apoptotic cell-derived bridging protein, although its corresponding phagocyte receptor still has to be identified (Arur et al., 2003; Fan et al., 2004). The serum proteins $\beta_{2}$-glycoprotein 1 ( $\left.\beta_{2} \mathrm{GP} 1\right)$, protein $S$, and growth arrestspecific gene 6 (Gas6) contribute to PS bridging as well and involve members of the LDL receptor-related protein family (LRP), or the protein tyrosine kinases Mer, Axl, and Tyro3, respectively (Ishimoto et al., 2000; Lu and Lemke, 2001; Scott et al., 2001; Anderson et al., 2003; Wu et al., 2005; Rothlin et al., 2007; Maiti et al., 2008; Xiong et al., 2008). Aside from externalized PS, several other "eat-me" signals on the surface of apoptosing cells have been described: sites resembling oxidized low density lipoprotein particles and sites binding thrombospondin-1, collectins or complement proteins have been reported to engage SRs, $\alpha_{\nu} \beta_{3 / 5}$ integrins, collectin and complement receptors in order to trigger dying cell engulfment. Finally, also the inactivation of "don'teat-me" signals, such as CD31 or CD47 and its binding partner $\operatorname{SIRP} \alpha$, which prevent viable cells from mistakenly being ingested, contributes to proper dying cell recognition (Brown et al., 2002; Gardai et al., 2005).

In case of primary and secondary necrosis the mechanisms of dying cell recognition and engulfment are not as well understood as in the case of apoptosis. However, it appears that complement opsonization rather represents a hallmark of secondary necrosis than of early apoptosis, and the same seems to apply to annexin A1 externalization (Gaipl et al., 2001; Blume et al., 2009). Moreover, although mechanistically different from PS translocation during apoptosis, ruptures or holes in the plasma membrane lead to an exposure of PS by primary and secondary necrotic cells. Consequently, PS has also been attributed a role in necrotic cell engulfment (Brouckaert et al., 2004; Bottcher et al., 2006). Of note, very recently the first specific "eat-me" signal of primary necrotic cells has been identified: exposed actin filaments, which are recognized by the C-type lectin Clec9A (Sancho et al., 2009; Ahrens et al., 2012; Zhang et al., 2012).

Ligation of engulfment receptors triggers rearrangements in the actin cytoskeleton and thus the internalization of the dying cell. However, the underlying molecular mechanisms are only poorly understood and may differ fundamentally according to the structure of the respective receptor and its downstream signaling cascades. Probably the most detailed data are available for BAI-1, a seven transmembrane domain G-protein coupled receptor that signals via the evolutionarily conserved ELMO1Dock180-Rac complex (Park et al., 2007). Undoubtedly, further studies are required in order to dissect the signaling cascades of each engulfment receptor. On the one hand this will help to understand why the morphology of apoptotic and necrotic cell ingestion is so different from each other, with apoptotic cells being phagocytosed by a "zipper"-like mechanism and necrotic cells - together with a substantial amount of extracellular material - being taken up by macropinocytosis (Krysko et al., 2006). On the other hand, it will contribute to elucidate, why the phagocytosis of apoptotic and necrotic cells is so fundamentally different in terms of the immunological outcome. 


\section{THE POST-PHAGOCYTIC IMMUNE RESPONSE}

After engulfing dying cells, macrophages and DCs exert discrepant functions regarding the subsequent immune response. Whereas macrophages predominantly degrade the phagocytic cargo and shape the cytokine milieu for other immune cells, DCs traffic the ingested material to MHC-II- or MHC-I-dependent pathways of antigen-presentation or cross-presentation, respectively. Of note, the immunological outcome of dying cell phagocytosis fundamentally differs depending on the type of death the internalized prey has previously undergone (Figure 2 ). It can be said very simplistically that the uptake of apoptotic cells blunts pro-inflammatory and induces anti-inflammatory cytokine production in macrophages, including IL-10, TGF- $\beta$, and PGE 2 (Voll etal., 1997; Fadok etal., 1998). DCs take up apoptotic material and process, present, or cross-present apoptotic cell-derived antigens to $\mathrm{T}$ cells, thus resulting in the induction of immune tolerance (Albert et al., 1998; Stuart et al., 2002; McGaha et al., 2011). The "tolerate-me" signals involved in this complex process are currently being elucidated, and PS, which is exposed on the apoptotic cell surface, apparently is of pivotal importance in this regard (Huynh et al., 2002; Chen et al., 2004; Doffek et al., 2011). However, due to holes in the plasma membrane, PS is also exposed by primary and secondary necro(pto)tic cells, but in this case dying cell engulfment triggers a potent pro-inflammatory immune response. So, somehow the tolerogenic effect of PS must be overridden. Exposed F-actin, which ligates Clec9A, efficiently stimulates cross-priming of damaged cell-derived antigens, but alone it is not sufficient to induce an adaptive immune response to dying cells (Ahrens et al., 2012). Evidence for the nature of the required molecules comes from a study reporting on the lack of pro-inflammatory responses against necrotic cells, which have been separated from their secretome and/or releasate (Brouckaert et al., 2004). Hence, it is obviously the plethora of molecules released during primary or secondary necro(pto)sis that tip the scale. Different studies have shown that these liberated components, including HMGB-1-decorated nucleosomes, HSPs, ATP, ribonucleosome particles, and others, trigger TLR-, C-type lectinand nod-like receptor-signaling, which is essential to promote proinflammatory cytokine production in macrophages and efficient cross-priming in DCs (Rovere-Querini et al., 2004; Blander, 2008; Ghiringhelli et al., 2009; Aymeric et al., 2010; Garaude et al., 2012; Figure 3). This is further substantiated by research in the field of autoimmunity as defects in the process of apoptotic cell clearance and the subsequent accumulation of secondary necrotic debris have been shown to represent hallmarks in the etiopathogenesis of chronic inflammatory and autoimmune diseases, such as systemic lupus erythematosus (SLE; Herrmann et al., 1998; Baumann et al., 2002; Gaipl et al., 2005, 2007a; Munoz et al., 2010a). Moreover, mice deficient in different engulfment genes or DNase II, which is required for the proper degradation of dying cell-derived DNA, reveal an accumulation of dying cell debris and develop a lateonset autoimmune phenotype, including the typical interferon (IFN) signature, closely resembling human SLE (Botto, 1998; Le et al., 2001; Cohen et al., 2002; Hanayama et al., 2006; Kawane et al., 2006).

In contrast to apoptotic and necro(pto)tic cells, the clearance of senescent cells is only poorly understood. Yet, a pioneering study has shown that senescence induction in established liver carcinomas results in the recruitment of macrophages, neutrophils, and natural killer (NK) cells, and this was sufficient for the clearance of the senescent tumor cells (Xue et al., 2007). However, which factors of the senescence-associated secretome are involved in this scenario (Figure 3), if senescent cells are "eaten up alive" or first are actively killed and then phagocytosed, and which "eatme" signals play a role in this context, remains elusive (Figure 4; Kuilman and Peeper, 2009; Coppe et al., 2010). Moreover, senescence induction in pre-cancerous hepatocytes was observed to stimulate an adaptive immune response depending on the interaction of antigen specific CD4 ${ }^{+} \mathrm{T}$ cells and macrophages (Kang et al., 2011). Whether this might be of use for the induction of anti-tumor immunity in established cancers has to be further evaluated.

It should be noted that the form of cell death or cell stress does not only shape the subsequent immune response, it has also profound impact on the surviving neighboring cells. In this regard, radiotherapy-induced apoptosis has been shown to potently promote tumor cell repopulation via mechanisms involving the caspase-3-dependent cleavage and activation of the calcium-independent phospholipase $\mathrm{A}_{2}\left(\mathrm{iPLA}_{2}\right)$ and the subsequent production of prostaglandin $\mathrm{E}_{2}$ ( $\mathrm{PGE}_{2}$; Huang et al., 2011; Lauber etal., 2011). Moreover, DAMPs released from necro(pto)tic cells and particularly HMGB-1 have been reported to stimulate autophagy as a mechanism of programed cell survival and thus to confer resistance to radiotherapy and chemotherapy in different models of leukemia, pancreatic, and colon cancer (Tang et al., 2010a,b; Liu et al., 2011a,b). As mentioned above, also the senescence-associated secretome contains factors, which can suppress or promote the proliferation of surviving neighboring cells, respectively (Kuilman and Peeper, 2009; Coppe et al., 2010). Presumably, these proliferation-stimulating effects of dying cells and their releasates represent integral parts of a conserved wound-healing program, which controls tissue regeneration and repair under physiological conditions. However, in the context of cancer therapy they might be counterproductive as therapy-induced tumor cell repopulation and/or therapy resistance would strongly interfere with the therapeutic aim of tumor eradication.

\section{DYING CELL CLEARANCE AND THE INDUCTION OF ANTI-TUMOR IMMUNE RESPONSES IN RESPONSE TO RADIOTHERAPY}

It is well acknowledged that the induction of tumor cell death and the abrogation of clonogenic survival by ionizing irradiation are key determinants of its therapeutic success. However, there is accumulating experimental evidence that particularly in the context of ablative radiotherapy, during which radiation is applied in high single doses of 10 Gy or more, complex immune mechanisms contribute to tumor regression. One of the initial reports on this issue showed that local high dose radiation therapy of transplanted mouse B16 melanoma stimulates the generation of tumor antigen-specific, IFN- $\gamma$ producing T cells (Lugade et al., 2005). In the same mouse model, ablative, but not fractionated radiotherapy was observed to drastically enhance $\mathrm{T}$ cell priming in tumor draining lymph nodes paralleled by a reduction/eradication of 


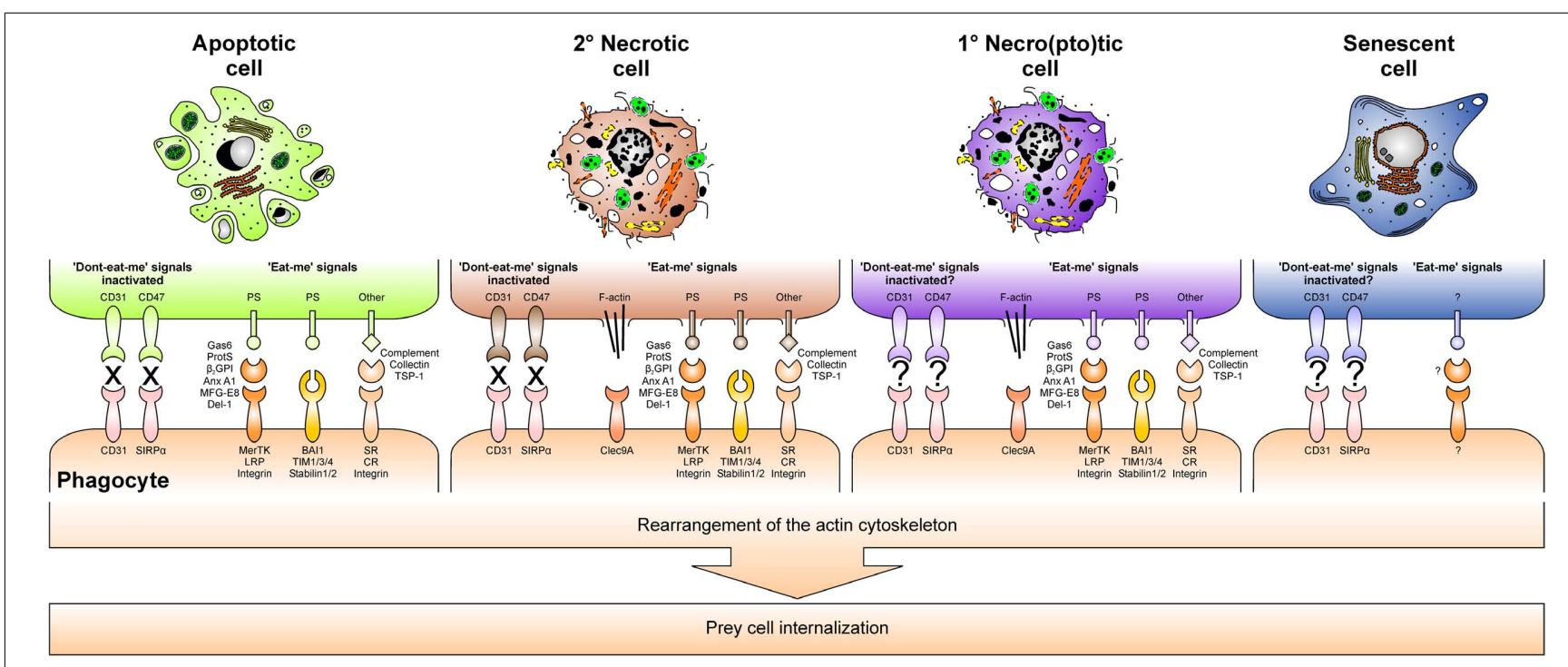

FIGURE 4 | "Eat-me" signals and inactivated "don't-eat-me" signals together with their respective phagocyte receptors orchestrate dying cell engulfment.

the primary tumor as well as distant metastases in a $\mathrm{CD} 8^{+} \mathrm{T}$ cell-dependent manner (Lee et al., 2009). A mechanistic explanation of how these $\mathrm{T}$ cells are primed was provided by a recent study showing that the intra-tumoral production of IFN- $\alpha / \beta$ in response to high dose radiotherapy enhances the cross-presenting capacity of tumor infiltrating DCs (Burnette et al., 2011). Hence, it appears that ablative radiotherapy triggers a temporal cascade of IFNs, which is well-known from the field of tumor immunoediting, where IFN- $\alpha / \beta$ produced by CD $11 c^{+}$cells (presumably DCs and macrophages) enhances the cross-priming activity of $\mathrm{CD} 8 \alpha^{+}$ DCs, thus stimulating the generation of IFN $-\gamma$ producing $\mathrm{CD}^{+} \mathrm{T}$ cells, and finally tumor rejection (Figure 5; Diamond et al., 2011; Fuertes et al., 2011). Notably, there is a clear difference in how IFN$\alpha / \beta$ and IFN- $\gamma$ contribute to a reduction in tumor burden. IFN- $\alpha / \beta$ predominantly affects macrophages, DCs, and NK cells leading to their activation and/or maturation, the upregulation of chemokine expression, the enhancement of antigen-presentation and crosspresentation by DCs and a robustly augmented induction of adaptive immune responses (Dunn et al., 2006). Consequently, in the context of cancer immunoediting, IFN- $\alpha / \beta$-responsiveness is specifically required in DCs and macrophages, whereas it appears to be dispensable in tumor cells (Diamond et al., 2011; Fuertes et al., 2011). Nevertheless, tumor rejection in response to radiotherapy might also be improved - at least in part - by a direct effect of IFN- $\alpha / \beta$ on the tumor via its reported capacity of radiosensitization (Morak et al., 2011). In strong contrast to IFN- $\alpha / \beta$, tumor cell responsiveness to IFN- $\gamma$ obviously is an essential prerequisite for the development of anti-tumor immune responses. Various antitumor mechanisms have been reported to be exerted by IFN- $\gamma$, including inhibition of tumor cell proliferation, apoptosis induction, inhibition of angiogenesis, and an overall enhancement of tumor immunogenicity as characterized by an upregulation of the MHC-I pathway, modulation/extension of the MHC-I ligandome, and downregulation of NKG2D ligands (Dunn et al., 2006; Reits et al., 2006; Lugade et al., 2008). Notwithstanding these direct effects on the tumor, IFN- $\gamma$ is key for the stimulation of an anti-tumor immune response. As such, IFN- $\gamma$ is vitally involved in $T_{H} 1 / T_{C} 1$ cell differentiation/activation, and it exerts similar effects as IFN- $\alpha / \beta$ in terms of innate immune cell activation and the promotion of DC-mediated antigen cross-presentation (Dunn et al., 2006).

Once more it should be emphasized that this IFN-controlled cascade of innate and adaptive immune responses was only observed in case of ablative but not conventional, fractionated radiotherapy (Lee et al., 2009). A feasible explanation for this might be that ablative and fractionated radiotherapy trigger different modalities of tumor cell death with only high dose irradiation stimulating primary and/or secondary necro(pto)sis. The corresponding liberation of danger signals, including HMGB-1 and ATP, in turn stimulates the TLR4-dependent production of IFN- $\alpha / \beta$ and other pro-inflammatory cytokines, initiating the above described IFN cascade and the DC-mediated instigation of anti-tumor $\mathrm{T}$ cell responses (Apetoh et al., 2007).

A key question that arises from an immuno-radiotherapeutic point of view at this point is: How can the process of dying cell clearance be instrumentalized or manipulated in order to enhance the efficacy of fractionated radiotherapy? Various putative approaches can be envisioned in this regard (Figure 6). The observations made with high dose ablative radiotherapy suggest that the temporary induction of primary/secondary tumor cell necro(pto)sis might be beneficial. Initial studies on this issue in fact provide evidence that the combination of radiotherapy with hyperthermia results in the induction of an immunogenic type of cell death as characterized by the release of danger signals, including HMGB-1 and HSP70, which foster the maturation of DCs in vitro (Schildkopf et al., 2009, 2010, 2011; Mantel et al., 2010). However, it remains to be elucidated, whether this translates into the productive stimulation of anti-tumor $\mathrm{T}$ cell responses 


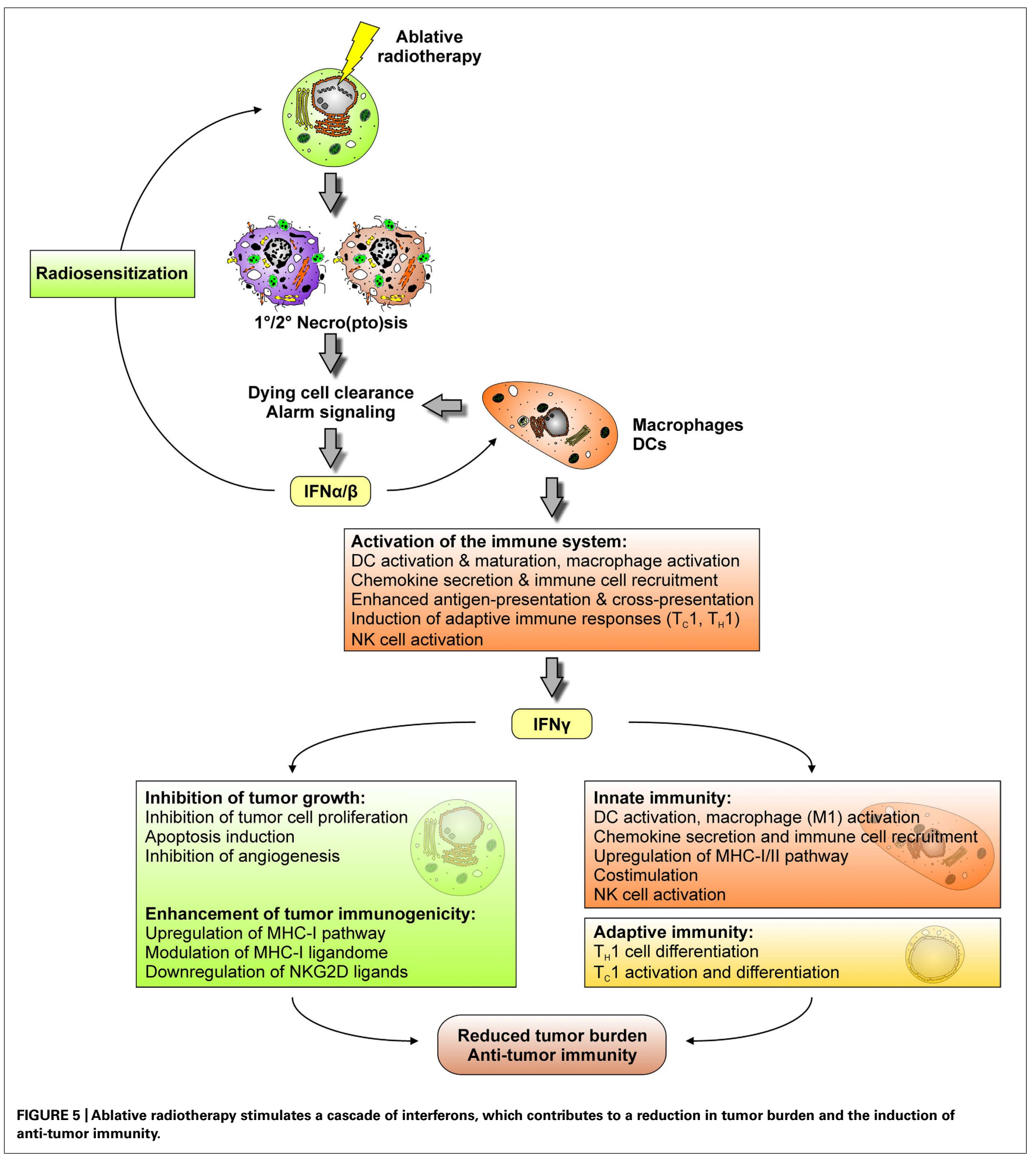

in vivo. Alternatively, radiotherapy might be combined with photodynamic therapy (PDT), since PDT has been reported to induce the expression of HSPs and the release of danger signals (Castano et al., 2006). Alone or in combination with chemotherapy PDT leads to the stimulation of anti-tumor $\mathrm{T}$ cell responses in vivo (Castano et al., 2008; Kammerer et al., 2011). Yet, if this holds also true for its combination with radiotherapy awaits further clarification. For tumors, which predominantly undergo apoptosis in response to fractionated radiotherapy, caspase inhibition might represent an approach to overcome the tolerogenic nature of this form of cell death, since caspase inhibition in apoptosing cells has been reported to directly trigger necroptosis (He et al., 


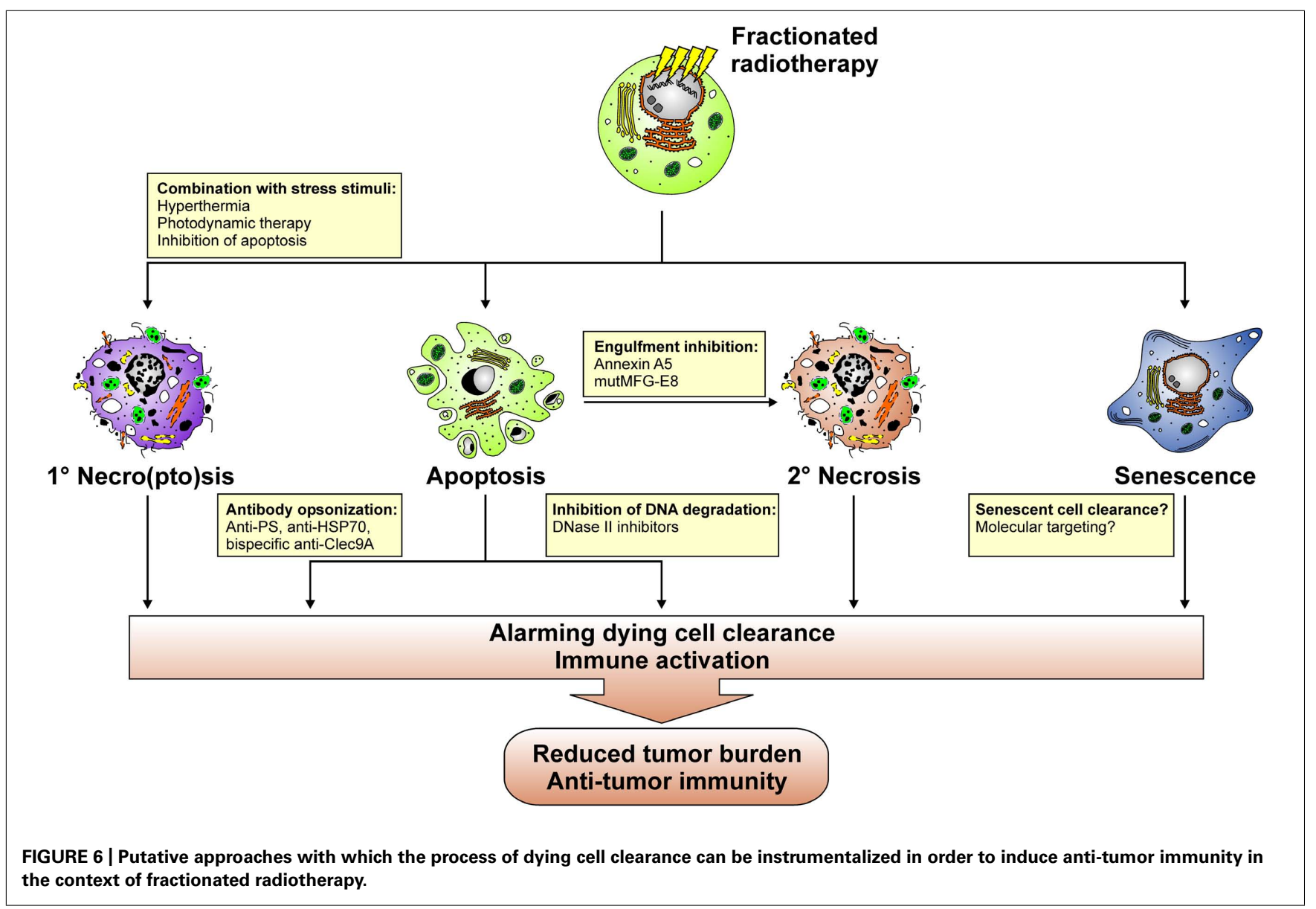

2009b). However, caspase inhibition might also confer radioresistance due to an overall inhibition of cell death. Therefore, the applicability of this approach has to be very carefully evaluated.

Directly interfering with apoptotic cell clearance in order to promote the accumulation of secondary necrotic tumor cell material might be an alternative approach to instigate the IFN cascade described above and a concomitant anti-tumor immune response. In this regard, annexin A5 and a mutant form of MFG-E8, which no longer is able to bind to the vitronectin receptor, might be valuable tools (Hanayama et al., 2002; Bondanza et al., 2004; Gaipl et al., 2007b; Munoz et al., 2007a,b; Frey et al., 2009). In a mouse model of tumor vaccination, annexin A5 has been shown to impair the uptake of irradiated apoptotic lymphoma cells by macrophages and to specifically target them to CD $8 \alpha^{+}$DCs, thus inducing the release of proinflammatory cytokines and tumorspecific immune memory, which contributed to the regression of growing tumors and conferred resistance against tumor rechallenge (Bondanza et al., 2004). Redirecting dying cell clearance toward Fc $\gamma$ receptor-mediated phagocytosis also appears a promising strategy for the induction of anti-tumor immune responses. For example, opsonization with autoantibodies has been reported to potently trigger FcyR-dependent phagocytosis of dying cells and subsequent pro-inflammatory cytokine production (Manfredi et al., 1998; Sarmiento et al., 2007; Grossmayer et al., 2008). Hence, "eat-me" signal specific antibodies, including anti-PS antibodies, or tumor antigen specific antibodies, like anti-HSP70 antibodies, might help to utilize pro-inflammatory dying cell phagocytosis for the induction of anti-tumor immunity (Ran et al., 2005; Gehrmann et al., 2008; He etal., 2009a; Stangl et al., 2011a,b). Engineering these antibodies into bi-specific antibodies coupling to Clec9A, is of special interest in this regard, since thereby dying tumor cell material could be specifically targeted toward the recycling endosomal compartment, thus favoring cross-presentation in $\mathrm{BDCA}^{+} \mathrm{DCs}$, the alleged human equivalent to mouse $\mathrm{CD} 8 \alpha^{+}$ DCs (Schreibelt et al., 2012). Seminal data obtained with different mouse models of viral vaccination point to the direction that this represents a successful approach of inducing vaccine-specific immune responses (Idoyaga et al., 2011; Iborra et al., 2012; Zelenay et al., 2012). It should be noted that Clec9A ligation alone is not sufficient to induce DC maturation and a concomitant adaptive immune response against dying cells (Ahrens et al., 2012). Coligation of additional receptors for DAMPs instead appears to be required. Research in the field of autoimmunity has convincingly shown that dying cell-derived nucleosomal material is very potent in this regard (Frisoni et al., 2007; Urbonaviciute et al., 2008). Hence, interfering with DNase II activity, which in phagocytes mediates the proper degradation of engulfed prey cell DNA, could represent a promising strategy to stimulate the described IFN cascade required for the induction of productive immune responses and well-known for its crucial role in the etiopathogenesis of 
autoimmune diseases, such as SLE (Kawane et al., 2006; MarshakRothstein, 2006; Deng and Tsao, 2010). To this end, cell-permeable, small molecule inhibitors of DNase II would be helpful, and it remains to be elucidated whether such compounds can technically be developed. Finally, further studies are required to improve and expand our knowledge on the process of senescent cell clearance with special focus on its applicability and potential utilization for the enhancement of tumor immunogenicity in the context of fractionated radiotherapy.

\section{CONCLUSION}

Undoubtedly, the induction of tumor cell death and the abrogation of clonogenic survival by ionizing irradiation are key to its therapeutic success. However, pioneering immuno-radiotherapeutic studies have convincingly shown that a contribution of complex immune mechanisms - particularly in the context of ablative radiotherapy - can no longer be neglected. The clearance of dying tumor cells by phagocytic cells of the innate immune system represents a crucial initiating step in this scenario. Valuable lessons can be learned from research in the field of autoimmunity on how the form of cell death skews the subsequent immune response, which cell types and molecules are involved in this context, and how these might be utilized for the induction of productive anti-tumor immune responses in combination with radiotherapy. Notably,

\section{REFERENCES}

Afshar, G., Jelluma, N., Yang, X., Basila, D., Arvold, N. D., Karlsson, A., Yount, G. L., Dansen, T. B., Koller, E., and Haas-Kogan, D. A. (2006). Radiation-induced caspase- 8 mediates p53-independent apoptosis in glioma cells. Cancer Res. 66, 4223-4232.

Ahrens, S., Zelenay, S., Sancho, D., Hanc, P., Kjaer, S., Feest, C., Fletcher, G., Durkin, C., Postigo, A., Skehel, M., Batista, F., Thompson, B., Way, M., Reis E Sousa, C., and Schulz, O. (2012). F-actin is an evolutionarily conserved damage-associated molecular pattern recognized by DNGR-1, a receptor for dead cells. Immunity 36, 635-645.

Albert, M. L., Pearce, S. F., Francisco, L. M., Sauter, B., Roy, P., Silverstein, R. L., and Bhardwaj, N. (1998). Immature dendritic cells phagocytose apoptotic cells via alphavbeta5 and CD36, and cross-present antigens to cytotoxic T lymphocytes. J. Exp. Med. 188, 1359-1368.

Anderson, H. A., Maylock, C. A., Williams, J. A., Paweletz, C. P., Shu, H., and Shacter, E. (2003). Serumderived protein $\mathrm{S}$ binds to phosphatidylserine and stimulates the phagocytosis of apoptotic cells. Nat. Immunol. 4, 87-91.

Apetoh, L., Ghiringhelli, F., Tesniere, A., Criollo, A., Ortiz, C., Lidereau, R., Mariette, C., Chaput, N., Mira, J. P., Delaloge, S., Andre, F., Tursz, T., Kroemer, G., and Zitvogel,
L. (2007). The interaction between HMGB1 and TLR4 dictates the outcome of anticancer chemotherapy and radiotherapy. Immunol. Rev. 220, 47-59.

Arur, S., Uche, U. E., Rezaul, K. Fong, M., Scranton, V., Cowan, A. E., Mohler, W., and Han, D. K. (2003). Annexin I is an endogenous ligand that mediates apoptotic cell engulfment. Dev. Cell 4, 587-598.

Aymeric, L., Apetoh, L., Ghiringhelli, F., Tesniere, A., Martins, I., Kroemer, G., Smyth, M. J., and Zitvogel, L. (2010). Tumor cell death and ATP release prime dendritic cells and efficient anticancer immunity. Cancer Res. 70, 855-858.

Baumann, I., Kolowos, W., Voll, R. E., Manger, B., Gaipl, U., Neuhuber, W. L., Kirchner, T., Kalden, J. R., and Herrmann, M. (2002). Impaired uptake of apoptotic cells into tingible body macrophages in germinal centers of patients with systemic lupus erythematosus. Arthritis Rheum. 46, 191-201.

Belka, C., Marini, P., Budach, W., Schulze-Osthoff, K., Lang, F., Gulbins, E., and Bamberg, M. (1998). Radiation-induced apoptosis in human lymphocytes and lymphoma cells critically relies on the up-regulation of CD95/Fas/APO-1 ligand. Radiat. Res. 149, 588-595.

Bianchi, M. E., and Manfredi, A. A. (2007). High-mobility group box 1 (HMGB1) protein at the crossroads between innate and adaptive

these immune responses would not only target the local tumor but could also reach distant, out-of-field metastases. To this end, combined, multi-modal treatment regimes have to be developed with the capacity to induce immunogenic forms of tumor cell death and concomitantly activate the immune system. The correct timing will be an essential parameter affecting the therapeutic success of these approaches, since the priming of adaptive immune responses takes place in the tumor draining lymph nodes, which due to the risk of tumor cell spread and metastasis formation are commonly removed by surgery. Hence, it might be worth considering - carefully and on an individualized basis - to postpone lymph node surgery until the initial anti-tumor immune priming has successfully been accomplished. Not only in this regard, the close collaboration of clinical radiation oncologist, surgeons, radiobiologists, molecular oncologists, and immunologists is indispensable in order to develop and optimize the personalized therapeutic regime with the highest benefit for each individual patient.

\section{ACKNOWLEDGMENTS}

This work was supported by the DFG (SFB 685 and SFB 914), LMU excellent, and Universität Bayern e.V. The authors have no competing financial interest and apologize to all colleagues in the field, whose work could not be cited due to space constraints.

immunity. Immunol. Rev. 220, 35-46.

Biswas, S. K., and Mantovani, A. (2010). Macrophage plasticity and interaction with lymphocyte subsets: cancer as a paradigm. Nat. Immunol. 11 , 889-896.

Blander, J. M. (2008). Phagocytosis and antigen presentation: a partnership initiated by Toll-like receptors. Ann. Rheum. Dis. 67(Suppl. 3), iii44-iii49.

Blume, K. E., Soeroes, S., Keppeler, H., Stevanovic, S., Kretschmer, D., Rautenberg, M., Wesselborg, S., and Lauber, K. (2012). Cleavage of annexin A1 by ADAM10 during secondary necrosis generates a monocytic "find-me" signal. J. Immunol. 188, 135-145.

Blume, K. E., Soeroes, S., Waibel, M., Keppeler, H., Wesselborg, S., Herrmann, M., Schulze-Osthoff, K., and Lauber, K. (2009). Cell surface externalization of annexin A1 as a failsafe mechanism preventing inflammatory responses during secondary necrosis. J. Immunol. 183, 8138-8147.

Bondanza, A., Zimmermann, V. S., Rovere-Querini, P., Turnay, J., Dumitriu, I. E., Stach, C. M., Voll, R. E., Gaipl, U. S., Bertling, W., Poschl, E., Kalden, J. R., Manfredi, A. A., and Herrmann, M. (2004). Inhibition of phosphatidylserine recognition heightens the immunogenicity of irradiated lymphoma cells in vivo. J. Exp. Med. 200, 1157-1165.

Bottcher, A., Gaipl, U. S., Furnrohr, B. G., Herrmann, M., Girkontaite, I.,
Kalden, J. R., and Voll, R. E. (2006). Involvement of phosphatidylserine, alphavbeta3, CD14, CD36, and complement $\mathrm{Clq}$ in the phagocytosis of primary necrotic lymphocytes by macrophages. Arthritis Rheum. 54, 927-938.

Botto, M. (1998). C1q knock-out mice for the study of complement deficiency in autoimmune disease. Exp. Clin. Immunogenet. 15, 231-234.

Bournazou, I., Pound, J. D., Duffin, R., Bournazos, S., Melville, L. A., Brown, S. B., Rossi, A. G., and Gregory, C. D. (2009). Apoptotic human cells inhibit migration of granulocytes via release of lactoferrin. J. Clin. Invest. 119, 20-32.

Brouckaert, G., Kalai, M., Krysko, D. V., Saelens, X., Vercammen, D., Ndlovu, M. N., Haegeman, G., D'Herde, K., and Vandenabeele, P. (2004). Phagocytosis of necrotic cells by macrophages is phosphatidylserine dependent and does not induce inflammatory cytokine production. Mol. Biol. Cell 15, 1089-1100.

Brown, S., Heinisch, I., Ross, E., Shaw, K., Buckley, C. D., and Savill, J. (2002). Apoptosis disables CD31-mediated cell detachment from phagocytes promoting binding and engulfment. Nature 418, 200-203.

Burnette, B. C., Liang, H., Lee, Y., Chlewicki, L., Khodarev, N. N., Weichselbaum, R. R., Fu, Y. X., and Auh, S. L. (2011). The efficacy of radiotherapy relies upon induction 
of type I interferon-dependent innate and adaptive immunity. Cancer Res. 71, 2488-2496

Castano, A. P., Mroz, P., and Hamblin, M. R. (2006). Photodynamic therapy and anti-tumour immunity. Nat. Rev. Cancer 6, 535-545.

Castano, A. P., Mroz, P., Wu, M. X., and Hamblin, M. R. (2008). Photodynamic therapy plus low-dose cyclophosphamide generates antitumor immunity in a mouse model. Proc. Natl. Acad. Sci. U.S.A. 105, 5495-5500.

Chalaris, A., Rabe, B., Paliga, K., Lange, H., Laskay, T., Fielding, C. A., Jones, S. A., RoseJohn, S., and Scheller, J. (2007). Apoptosis is a natural stimulus of IL6R shedding and contributes to the proinflammatory trans-signaling function of neutrophils. Blood 110 1748-1755.

Chen, X., Doffek, K., Sugg, S. L., and Shilyansky, J. (2004). Phosphatidylserine regulates the maturation of human dendritic cells. $J$. Immunol. 173, 2985-2994.

Cohen, P. L., Caricchio, R., Abraham, V., Camenisch, T. D., Jennette, J. C., Roubey, R. A., Earp, H. S., Matsushima, G., and Reap, E. A. (2002). Delayed apoptotic cell clearance and lupus-like autoimmunity in mice lacking the c-mer membrane tyrosine kinase. J. Exp. Med. 196, 135-140.

Coppe, J. P., Desprez, P. Y., Krtolica, A., and Campisi, J. (2010). The senescence-associated secretory phenotype: the dark side of tumor suppression. Annu. Rev. Pathol. 5, 99-118.

Debatin, K. M., and Krammer, P. H. (2004). Death receptors in chemotherapy and cancer. Oncogene 23, 2950-2966.

Deng, Y., and Tsao, B. P. (2010). Genetic susceptibility to systemic lupus erythematosus in the genomic era. Nat. Rev. Rheumatol. 6, 683-692.

Diamond, M. S., Kinder, M., Matsushita, H., Mashayekhi, M., Dunn, G. P., Archambault, J. M., Lee, H., Arthur, C. D., White, J. M., Kalinke, U., Murphy, K. M., and Schreiber, R. D. (2011). Type I interferon is selectively required by dendritic cells for immune rejection of tumors. J. Exp. Med. 208, 1989-2003.

Doffek, K., Chen, X., Sugg, S. L., and Shilyansky, J. (2011). Phosphatidylserine inhibits NFKB and p38 MAPK activation in human monocyte derived dendritic cells. Mol. Immunol. 48, 1771-1777.

Dunn, G. P., Koebel, C. M., and Schreiber, R. D. (2006). Interferons, immunity and cancer immunoediting. Nat. Rev. Immunol. 6, 836-848.

Elliott, M. R., Chekeni, F. B., Trampont, P. C., Lazarowski, E. R., Kadl, A., Walk, S. F., Park, D., Woodson, R. I., Ostankovich, M., Sharma P., Lysiak, J. J., Harden, T. K., Leitinger, N., and Ravichandran, K. S. (2009). Nucleotides released by apoptotic cells act as a find-me signal to promote phagocytic clearance. Nature 461, 282-286.

Eriksson, D., and Stigbrand, T. (2010). Radiation-induced cell death mechanisms. Tumour Biol. 31, 363-372.

Eue, I., Pietz, B., Storck, J., Klempt, M., and Sorg, C. (2000). Transendothelial migration of $27 \mathrm{E} 10+$ human monocytes. Int. Immunol. 12, 1593-1604.

Fadok, V. A., Bratton, D. L., Konowal, A., Freed, P. W., Westcott, J. Y., and Henson, P. M. (1998). Macrophages that have ingested apoptotic cells in vitro inhibit proinflammatory cytokine production through autocrine/paracrine mechanisms involving TGF-beta, PGE2, and PAF. J. Clin. Invest. 101, 890-898.

Fadok, V. A., Voelker, D. R., Campbell, P. A., Cohen, J. J., Bratton, D. L., and Henson, P. M. (1992) Exposure of phosphatidylserine on the surface of apoptotic lymphocytes triggers specific recognition and removal by macrophages. J. Immunol. 148, 2207-2216.

Fan, X., Krahling, S., Smith, D. Williamson, P., and Schlegel, R. A. (2004). Macrophage surface expression of annexins I and II in the phagocytosis of apoptotic lymphocytes. Mol. Biol. Cell 15, 2863-2872.

Frey, B., Schildkopf, P., Rodel, F., Weiss, E. M., Munoz, L. E., Herrmann, M., Fietkau, R., and Gaipl, U. S. (2009). AnnexinA5 renders dead tumor cells immunogenic - implications for multimodal cancer therapies. J. Immunotoxicol. 6, 209-216.

Frisoni, L., Mcphie, L., Kang, S. A., Monestier, M., Madaio, M., Satoh, M., and Caricchio, R. (2007). Lack of chromatin and nuclear fragmentation in vivo impairs the production of lupus anti-nuclear antibodies. $J$. Immunol. 179, 7959-7966.

Fuertes, M. B., Kacha, A. K., Kline, J., Woo, S. R., Kranz, D. M., Murphy, K. M., and Gajewski, T. F. (2011). Host type I IFN signals are required for antitumor CD8 $+\mathrm{T}$ cell responses through CD8 $\{$ alpha $\}+$ dendritic cells. J. Exp. Med. 208, 2005-2016.

Gaipl, U. S., Kuenkele, S., Voll, R. E., Beyer, T. D., Kolowos, W., Heyder, P., Kalden, J. R., and Herrmann, M.
(2001). Complement binding is an early feature of necrotic and a rather late event during apoptotic cell death. Cell Death Differ. 8, 327-334.

Gaipl, U. S., Munoz, L. E., Grossmayer, G., Lauber, K., Franz, S., Sarter, K., Voll, R. E., Winkler, T., Kuhn, A., Kalden, J., Kern, P., and Herrmann, M. (2007a). Clearance deficiency and systemic lupus erythematosus (SLE). J. Autoimmun. 28, 114-121.

Gaipl, U. S., Munoz, L. E., Rodel, F., Pausch, F., Frey, B., Brachvogel, B., Von Der Mark, K., and Poschl, E. (2007b). Modulation of the immune system by dying cells and the phosphatidylserineligand annexin A5. Autoimmunity 40, 254-259.

Gaipl, U. S., Voll, R. E., Sheriff, A. Franz, S., Kalden, J. R., and Herrmann, M. (2005). Impaired clearance of dying cells in systemic lupus erythematosus. Autoimmun. Rev. 4 , 189-194.

Galluzzi, L., Vitale, I., Abrams, J. M., Alnemri, E. S., Baehrecke, E. H. Blagosklonny, M. V., Dawson, T. M., Dawson, V. L., El-Deiry, W. S., Fulda, S., Gottlieb, E., Green, D. R., Hengartner, M. O., Kepp, O., Knight, R. A., Kumar, S., Lipton, S. A., Lu, X., Madeo, F., Malorni, W., Mehlen, P., Nunez, G., Peter, M. E., Piacentini, M., Rubinsztein, D. C., Shi, Y., Simon, H. U., Vandenabeele, P., White, E., Yuan, J., Zhivotovsky, B., Melino, G., and Kroemer, G. (2012). Molecular definitions of cell death subroutines: recommendations of the Nomenclature Committee on Cell Death 2012. Cell Death Differ. 19, 107-120.

Garaude, J., Kent, A., Van Rooijen, N., and Blander, J. M. (2012). Simultaneous targeting of Toll- and nod-like receptors induces effective tumor-specific immune responses. Sci. Transl. Med. 4, 120ra116.

Gardai, S. J., Mcphillips, K. A., Frasch, S. C., Janssen, W. J., Starefeldt, A., Murphy-Ullrich, J. E., Bratton, D. L., Oldenborg, P. A., Michalak, M., and Henson, P. M. (2005). Cellsurface calreticulin initiates clearance of viable or apoptotic cells through trans-activation of LRP on the phagocyte. Cell 123, 321-334.

Gehrmann, M., Liebisch, G., Schmitz, G., Anderson, R., Steinem, C. De Maio, A., Pockley, G., and Multhoff, G. (2008). Tumor-specific Hsp70 plasma membrane localization is enabled by the glycosphingolipid Gb3. PLoS ONE 3, e1925. doi: 10.1371/journal.pone.0001925

Ghiringhelli, F., Apetoh, L., Tesniere, A., Aymeric, L., Ma, Y., Ortiz, C., Vermaelen, K., Panaretakis, T., Mignot,
G., Ullrich, E., Perfettini, J. L., Schlemmer, F., Tasdemir, E., Uhl, M., Genin, P., Civas, A., Ryffel, B., Kanellopoulos, J., Tschopp, J., Andre, F., Lidereau, R., Mclaughlin, N. M., Haynes, N. M., Smyth, M. J., Kroemer, G., and Zitvogel, L. (2009). Activation of the NLRP3 inflammasome in dendritic cells induces IL-1beta-dependent adaptive immunity against tumors. Nat. Med. 15, 1170-1178.

Grossmayer, G. E., Munoz, L. E., Weber, C. K., Franz, S., Voll, R. E., Kern, P. M., Kalden, J. R., Schett, G., Herrmann, M., and Gaipl, U. S. (2008). IgG autoantibodies bound to surfaces of necrotic cells and complement C4 comprise the phagocytosis promoting activity for necrotic cells of systemic lupus erythaematosus sera. Ann. Rheum. Dis. 67, 1626-1632.

Gude, D. R., Alvarez, S. E., Paugh, S. W., Mitra, P., Yu, J., Griffiths, R., Barbour, S. E., Milstien, S., and Spiegel, S. (2008). Apoptosis induces expression of sphingosine kinase 1 to release sphingosine-1-phosphate as a "come-and-get-me" signal. FASEB J. 22, 2629-2638.

Hanayama, R., Miyasaka, K., Nakaya, M., and Nagata, S. (2006). MFGE8-dependent clearance of apoptotic cells, and autoimmunity caused by its failure. Curr. Dir. Autoimmun. 9, 162-172.

Hanayama, R., Tanaka, M., Miwa, K., Shinohara, A., Iwamatsu, A., and Nagata, S. (2002). Identification of a factor that links apoptotic cells to phagocytes. Nature 417, 182-187.

Haupt, S., Berger, M., Goldberg, Z., and Haupt, Y. (2003). Apoptosis - the p53 network. J. Cell Sci. 116, 4077-4085.

He, J., Yin, Y., Luster, T. A., Watkins, L., and Thorpe, P. E. (2009a). Antiphosphatidylserine antibody combined with irradiation damages tumor blood vessels and induces tumor immunity in a rat model of glioblastoma. Clin. Cancer Res. 15, 6871-6880.

He, S., Wang, L., Miao, L., Wang, T., Du, F., Zhao, L., and Wang, X. (2009b). Receptor interacting protein kinase-3 determines cellular necrotic response to TNF-alpha. Cell 137, 1100-1111.

Herrmann, M., Voll, R. E., Zoller, O. M., Hagenhofer, M., Ponner, B. B., and Kalden, J. R. (1998). Impaired phagocytosis of apoptotic cell material by monocyte-derived macrophages from patients with systemic lupus erythematosus. Arthritis Rheum. 41, 1241-1250.

Hou, Y., Plett, P. A., Ingram, D. A., Rajashekhar, G., Orschell, C. M., Yoder, M. C., March, K. L., 
and Clauss, M. (2006). Endothelialmonocyte-activating polypeptide II induces migration of endothelial progenitor cells via the chemokine receptor CXCR3. Exp. Hematol. 34, 1125-1132.

Huang, Q., Li, F., Liu, X., Li, W., Shi, W., Liu, F. F., O’Sullivan, B., He, Z., Peng, Y., Tan, A. C., Zhou, L., Shen, J., Han, G., Wang, X. J., Thorburn, J., Thorburn, A., Jimeno, A., Raben, D., Bedford, J. S., and Li, C. Y. (2011). Caspase 3-mediated stimulation of tumor cell repopulation during cancer radiotherapy. Nat. Med. 17, 860-866.

Hurley, P. J., and Bunz, F. (2007). ATM and ATR: components of an integrated circuit. Cell Cycle 6, 414-417.

Huynh, M. L., Fadok, V. A., and Henson, P. M. (2002). Phosphatidylserinedependent ingestion of apoptotic cells promotes TGF-betal secretion and the resolution of inflammation. J. Clin. Invest. 109, 41-50.

Iborra, S., Izquierdo, H. M., MartinezLopez, M., Blanco-Menendez, N., Reis, E. S. C., and Sancho, D. (2012). The DC receptor DNGR-1 mediates cross-priming of CTLs during vaccinia virus infection in mice. J. Clin. Invest. 122, 1628-1643.

Idoyaga, J., Lubkin, A., Fiorese, C., Lahoud, M. H., Caminschi, I., Huang, Y., Rodriguez, A., Clausen, B. E., Park, C. G., Trumpfheller, C., and Steinman, R. M. (2011). Comparable T helper 1 (Th1) and CD8 T-cell immunity by targeting HIV gag p24 to CD8 dendritic cells within antibodies to Langerin, DEC205, and Clec9A. Proc. Natl. Acad. Sci. U.S.A. 108, 2384-2389.

Ishimoto, Y., Ohashi, K., Mizuno, K., and Nakano, T. (2000). Promotion of the uptake of PS liposomes and apoptotic cells by a product of growth arrest-specific gene, gas6. J. Biochem. 127, 411-417.

Jackson, S. P., and Bartek, J. (2009). The DNA-damage response in human biology and disease. Nature 461, 1071-1078.

Kammerer, R., Buchner, A., Palluch, P., Pongratz, T., Oboukhovskij, K., Beyer, W., Johansson, A., Stepp, H., Baumgartner, R., and Zimmermann, W. (2011). Induction of immune mediators in glioma and prostate cancer cells by non-lethal photodynamic therapy. PLoS ONE 6, e21834. doi: 10.1371/journal.pone.0021834

Kang, T. W., Yevsa, T., Woller, N., Hoenicke, L., Wuestefeld, T., Dauch, D., Hohmeyer, A., Gereke, M., Rudalska, R., Potapova, A., Iken, M., Vucur, M., Weiss, S., Heikenwalder, M., Khan, S., Gil, J., Bruder, D., Manns,
M., Schirmacher, P., Tacke, F., Ott, M., Luedde, T., Longerich, T., Kubicka, S., and Zender, L. (2011). Senescence surveillance of pre-malignant hepatocytes limits liver cancer development. Nature 479, 547-551.

Kawane, K., Ohtani, M., Miwa, K., Kizawa, T., Kanbara, Y., Yoshioka Y., Yoshikawa, H., and Nagata, S. (2006). Chronic polyarthritis caused by mammalian DNA that escapes from degradation in macrophages. Nature 443, 998-1002.

Kobayashi, N., Karisola, P., Pena-Cruz, V., Dorfman, D. M., Jinushi, M., Umetsu, S. E., Butte, M. J., Nagumo, H., Chernova, I., Zhu, B., Sharpe, A. H., Ito, S., Dranoff, G., Kaplan, G. G., Casasnovas, J. M., Umetsu, D. T., Dekruyff, R. H., and Freeman, G. J. (2007). TIM-1 and TIM-4 glycoproteins bind phosphatidylserine and mediate uptake of apoptotic cells. Immunity 27, 927-940.

Krahling, S., Callahan, M. K. Williamson, P., and Schlegel, R. A. (1999). Exposure of phosphatidylserine is a general feature in the phagocytosis of apoptotic lymphocytes by macrophages. Cell Death Differ. 6, 183-189.

Krysko, D. V., Denecker, G., Festjens, N., Gabriels, S., Parthoens, E., D'Herde, K., and Vandenabeele, P. (2006). Macrophages use different internalization mechanisms to clear apoptotic and necrotic cells. Cell Death Differ. 13, 2011-2022.

Kuilman, T., and Peeper, D. S. (2009). Senescence-messaging secretome: SMS-ing cellular stress. Nat. Rev. Cancer 9, 81-94.

Lauber, K., Blumenthal, S. G., Waibel, M., and Wesselborg, S. (2004). Clearance of apoptotic cells: getting rid of the corpses. Mol. Cell 14, 277-287.

Lauber, K., Bohn, E., Krober, S. M., Xiao, Y. J., Blumenthal, S. G., Lindemann, R. K., Marini, P., Wiedig, C., Zobywalski, A., Baksh, S., Xu, Y., Autenrieth, I. B., SchulzeOsthoff, K., Belka, C., Stuhler, G., and Wesselborg, S. (2003). Apoptotic cells induce migration of phagocytes via caspase-3-mediated release of a lipid attraction signal. Cell 113, 717-730.

Lauber, K., Munoz, L. E., Berens, C., Jendrossek, V., Belka, C., and Herrmann, M. (2011). Apoptosis induction and tumor cell repopulation: the yin and yang of radiotherapy. Radiat. Oncol. 6,176 .

Le, L. Q., Kabarowski, J. H., Weng, Z., Satterthwaite, A. B., Harvill, E. T., Jensen, E. R., Miller, J. F., and Witte, O. N. (2001). Mice lacking the orphan $\mathrm{G}$ protein-coupled receptor
G2A develop a late-onset autoimmune syndrome. Immunity 14, 561-571.

Lee, Y., Auh, S. L., Wang, Y., Burnette, B., Meng, Y., Beckett, M., Sharma, R., Chin, R., Tu, T., Weichselbaum, R. R., and Fu, Y. X. (2009). Therapeutic effects of ablative radiation on local tumor require CD8+ T cells: changing strategies for cancer treatment. Blood 114, 589-595.

Levine, A. J. (1997). p53, the cellular gatekeeper for growth and division. Cell 88, 323-331.

Liu, L., Yang, M., Kang, R., Wang, Z., Zhao, Y., Yu, Y., Xie, M., Yin, X., Livesey, K. M., Lotze, M. T., Tang, D., and Cao, L. (2011a). HMGB1-induced autophagy promotes chemotherapy resistance in leukemia cells. Leukemia 25, 23-31.

Liu, L., Yang, M., Kang, R., Wang, Z., Zhao, Y., Yu, Y., Xie, M., Yin, X., Livesey, K. M., Loze, M. T., Tang, D., and Cao, L. (2011b). DAMPmediated autophagy contributes to drug resistance. Autophagy 7 112-114.

Lotze, M. T., Zeh, H. J., Rubartelli, A., Sparvero, L. J., Amoscato, A. A., Washburn, N. R., Devera, M. E., Liang, X., Tor, M., and Billiar, T. (2007). The grateful dead: damage-associated molecular pattern molecules and reduction/oxidation regulate immunity. Immunol. Rev. 220, 60-81.

Lu, Q., and Lemke, G. (2001). Homeostatic regulation of the immune system by receptor tyrosine kinases of the Tyro 3 family. Science 293, 306-311.

Lugade, A. A., Moran, J. P., Gerber, S. A., Rose, R. C., Frelinger, J. G., and Lord, E. M. (2005). Local radiation therapy of B16 melanoma tumors increases the generation of tumor antigenspecific effector cells that traffic to the tumor. J. Immunol. 174, 7516-7523.

Lugade, A. A., Sorensen, E. W., Gerber, S. A., Moran, J. P., Frelinger, J. G., and Lord, E. M. (2008). Radiation-induced IFNgamma production within the tumor microenvironment influences antitumor immunity. J. Immunol. 180, 3132-3139.

Maiti, S. N., Balasubramanian, K., Ramoth, J. A., and Schroit, A J. (2008). Beta-2-glycoprotein 1dependent macrophage uptake of apoptotic cells. Binding to lipoprotein receptor-related protein receptor family members. J. Biol. Chem. 283, 3761-3766.

Manfredi, A. A., Rovere, P., Galati, G., Heltai, S., Bozzolo, E., Soldini, L., Davoust, J., Balestrieri, G., Tincani,
A., and Sabbadini, M. G. (1998). Apoptotic cell clearance in systemic lupus erythematosus. I. Opsonization by antiphospholipid antibodies. Arthritis Rheum. 41, 205-214.

Mantel, F., Frey, B., Haslinger, S., Schildkopf, P., Sieber, R., Ott, O. J., Lodermann, B., Rodel, F., Sauer, R., Fietkau, R., and Gaipl, U. S. (2010). Combination of ionising irradiation and hyperthermia activates programmed apoptotic and necrotic cell death pathways in human colorectal carcinoma cells. Strahlenther. Onkol. 186, 587-599.

Marshak-Rothstein, A. (2006). Tolllike receptors in systemic autoimmune disease. Nat. Rev. Immunol. 6, 823-835.

Matzinger, P. (1998). An innate sense of danger. Semin. Immunol. 10, 399-415.

McGaha, T. L., Chen, Y., Ravishankar, B., Van Rooijen, N., and Karlsson, M. C. (2011). Marginal zone macrophages suppress innate and adaptive immunity to apoptotic cells in the spleen. Blood 117, 5403-5412.

Meek, D. W. (2009). Tumour suppression by p53: a role for the DNA damage response? Nat. Rev. Cancer 9, 714-723.

Miyanishi, M., Tada, K., Koike, M., Uchiyama, Y., Kitamura, T., and Nagata, S. (2007). Identification of Tim 4 as a phosphatidylserine receptor. Nature 450, 435-439.

Morak, M. J., Van Koetsveld, P. M., Kanaar, R., Hofland, L. J., and Van Eijck, C. H. (2011). Type I interferons as radiosensitisers for pancreatic cancer. Eur. J. Cancer 47, 1938-1945.

Munoz, L. E., Franz, S., Pausch, F., Furnrohr, B., Sheriff, A., Vogt, B., Kern, P. M., Baum, W., Stach, C., Von Laer, D., Brachvogel, B., Poschl, E., Herrmann, M., and Gaipl, U. S. (2007a). The influence on the immunomodulatory effects of dying and dead cells of Annexin V. J. Leukoc. Biol. 81, 6-14. Munoz, L. E., Frey, B., Pausch, F., Baum, W., Mueller, R. B., Brachvogel, B., Poschl, E., Rodel, F., Von Der Mark, K., Herrmann, M., and Gaipl, U. S. (2007b). The role of annexin A5 in the modulation of the immune response against dying and dead cells. Curr. Med. Chem. 14, 271-277.

Munoz, L. E., Lauber, K., Schiller, M., Manfredi, A. A., and Herrmann, M. (2010a). The role of defective clearance of apoptotic cells in systemic autoimmunity. Nat. Rev. Rheumatol. 6, 280-289.

Munoz, L. E., Peter, C., Herrmann, M., Wesselborg, S., and Lauber, K. (2010b). Scent of dying cells: the role of attraction signals in the clearance 
of apoptotic cells and its immunological consequences. Autoimmun. Rev. 9, 425-430.

Nakayama, M., Akiba, H., Takeda, K., Kojima, Y., Hashiguchi, M., Azuma, M., Yagita, H., and Okumura, K. (2009). Tim-3 mediates phagocytosis of apoptotic cells and cross-presentation. Blood 113, 3821-3830.

Nardella, C., Clohessy, J. G., Alimonti, A., and Pandolfi, P. P. (2011). Prosenescence therapy for cancer treatment. Nat. Rev. Cancer 11, 503-511.

Nishiura, H., Shibuya, Y., and Yamamoto, T. (1998). S19 ribosomal protein cross-linked dimer causes monocyte-predominant infiltration by means of molecular mimicry to complement C5a. Lab. Invest. 78, 1615-1623.

Park, D., Tosello-Trampont, A. C., Elliott, M. R., Lu, M., Haney, L. B., Ma, Z., Klibanov, A. L., Mandell, J. W., and Ravichandran, K. S. (2007). BAI1 is an engulfment receptor for apoptotic cells upstream of the ELMO/Dock180/Rac module. Nature 450, 430-434.

Park, S. Y., Jung, M. Y., Kim, H. J., Lee, S. J., Kim, S. Y., Lee, B. H., Kwon, T. H., Park, R. W., and Kim, I. S. (2008). Rapid cell corpse clearance by stabilin-2, a membrane phosphatidylserine receptor. Cell Death Differ. 15, 192-201.

Park, S. Y., Jung, M. Y., Lee, S. J., Kang, K. B., Gratchev, A., Riabov, V., Kzhyshkowska, J., and Kim, I. S. (2009). Stabilin-1 mediates phosphatidylserine-dependent clearance of cell corpses in alternatively activated macrophages. J. Cell Sci. 122, 3365-3373.

Peter, C., Waibel, M., Radu, C. G., Yang, L. V., Witte, O. N., Schulze-Osthoff, K., Wesselborg, S., and Lauber, K. (2008). Migration to apoptotic "findme" signals is mediated via the phagocyte receptor G2A. J. Biol. Chem. 283, 5296-5305.

Peter, C., Wesselborg, S., Herrmann, M., and Lauber, K. (2010). Dangerous attraction: phagocyte recruitment and danger signals of apoptotic and necrotic cells. Apoptosis 15, 10071028.

Ran, S., He, J., Huang, X., Soares, M., Scothorn, D., and Thorpe, P. E. (2005). Antitumor effects of a monoclonal antibody that binds anionic phospholipids on the surface of tumor blood vessels in mice. Clin. Cancer Res. 11, 1551-1562.

Ravichandran, K. S. (2010). Find-me and eat-me signals in apoptotic cell clearance: progress and conundrums. J. Exp. Med. 207, 1807-1817.
Ravichandran, K. S. (2011). Beginnings of a good apoptotic meal: the findme and eat-me signaling pathways. Immunity 35, 445-455.

Reed, J. C. (2006). Drug insight: cancer therapy strategies based on restoration of endogenous cell death mechanisms. Nat. Clin. Pract. Oncol. 3, 388-398.

Reits, E. A., Hodge, J. W., Herberts, C. A., Groothuis, T. A., Chakraborty, M., Wansley, E. K., Camphausen, K., Luiten, R. M., De Ru, A. H., Neijssen, J., Griekspoor, A., Mesman, E., Verreck, F. A., Spits, H., Schlom, J., Van Veelen, P., and Neefjes, J. J. (2006). Radiation modulates the peptide repertoire, enhances $\mathrm{MHC}$ class I expression, and induces successful antitumor immunotherapy. J. Exp. Med. 203, 1259-1271.

Rothlin, C. V., Ghosh, S., Zuniga, E. I., Oldstone, M. B., and Lemke, G. (2007). TAM receptors are pleiotropic inhibitors of the innate immune response. Cell 131, 1124-1136.

Rovere-Querini, P., Capobianco, A., Scaffidi, P., Valentinis, B., Catalanotti, F., Giazzon, M., Dumitriu, I. E., Muller, S., Iannacone, M., Traversari, C., Bianchi, M. E., and Manfredi, A. A. (2004). HMGB1 is an endogenous immune adjuvant released by necrotic cells. EMBO Rep. 5, 825-830.

Rudner, J., Belka, C., Marini, P., Wagner, R. J., Faltin, H., Lepple-Wienhues, A. Bamberg, M., and Budach, W. (2001). Radiation sensitivity and apoptosis in human lymphoma cells. Int. J. Radiat. Biol. 77, 1-11.

Sancho, D., Joffre, O. P., Keller, A. M. Rogers, N. C., Martinez, D., HernanzFalcon, P., Rosewell, I., Reis, E., and Sousa, C. (2009). Identification of a dendritic cell receptor that couples sensing of necrosis to immunity. Nature 458, 899-903.

Sarmiento, L. F., Munoz, L. E., Chirinos, P., Bianco, N. E., and ZabaletaLanz, M. E. (2007). Opsonization by anti-dsDNA antibodies of apoptotic cells in systemic lupus erythematosus. Autoimmunity 40, 337-339.

Schildkopf, P., Frey, B., Mantel, F., Ott, O. J., Weiss, E. M., Sieber, R., Janko, C., Sauer, R., Fietkau, R., and Gaipl, U. S. (2010). Application of hyperthermia in addition to ionizing irradiation fosters necrotic cell death and HMGB1 release of colorectal tumor cells. Biochem. Biophys. Res. Commun. 391, 1014-1020.

Schildkopf, P., Frey, B., Ott, O. J., Rubner, Y., Multhoff, G., Sauer, R., Fietkau, R., and Gaipl, U. S. (2011). Radiation combined with hyperthermia induces HSP70dependent maturation of dendritic cells and release of pro-inflammatory cytokines by dendritic cells and macrophages. Radiother. Oncol. 101, 109-115.

Schildkopf, P., Holmer, R., Sieber, R., Ott, O. J., Janko, C., Mantel, F., Frey, B., Fietkau, R., and Gaipl, U. S. (2009). Hyperthermia in com bination with $\mathrm{X}$-irradiation induces inflammatory forms of cell death. Autoimmunity 42, 311-313.

Schreibelt, G., Klinkenberg, L. J., Cruz, L. J., Tacken, P. J., Tel, J., Kreutz, M., Adema, G. J., Brown, G. D., Figdor, C. G., and De Vries, I. J. (2012). The C-type lectin receptor CLEC9A mediates antigen uptake and (cross-)presentation by human blood BDCA3+ myeloid dendritic cells. Blood 119, 2284-2292.

Scott, R. S., Mcmahon, E. J., Pop, S. M., Reap, E. A., Caricchio, R., Cohen, P. L., Earp, H. S., and Matsushima, G. K. (2001). Phagocytosis and clearance of apoptotic cells is mediated by MER. Nature 411, 207-211.

Segundo, C., Medina, F., Rodriguez, C. Martinez-Palencia, R., Leyva-Cobian, F., and Brieva, J. A. (1999). Surface molecule loss and bleb formation by human germinal center B cells undergoing apoptosis: role of apoptotic blebs in monocyte chemotaxis. Blood 94, 1012-1020.

Sengupta, S., and Harris, C. C. (2005). p53: traffic cop at the crossroads of DNA repair and recombination. Nat. Rev. Mol. Cell Biol. 6, 44-55.

Shi, Y., Mucsi, A. D., and Ng, G. (2010). Monosodium urate crystals in inflammation and immunity. Immunol. Rev. 233, 203-217.

Shichita, T., Hasegawa, E., Kimura, A., Morita, R., Sakaguchi, R., Takada, I., Sekiya, T., Ooboshi, H., Kitazono, T., Yanagawa, T., Ishii, T., Takahashi, H., Mori, S., Nishibori, M., Kuroda, K., Akira, S., Miyake, K., and Yoshimura, A. (2012). Peroxiredoxin family proteins are key initiators of post-ischemic inflammation in the brain. Nat. Med. 18, 911-917.

Shiloh, Y. (2006). The ATM-mediated DNA-damage response: taking shape. Trends Biochem. Sci. 31, 402-410.

Silva, M. T. (2010). Secondary necrosis: the natural outcome of the complete apoptotic program. FEBS Lett. 584, 4491-4499.

Smith, J., Tho, L. M., Xu, N., and Gillespie, D. A. (2010). The ATMChk2 and ATR-Chk1 pathways in DNA damage signaling and cancer. Adv. Cancer Res. 108, 73-112.

Stangl, S., Gehrmann, M., Riegger, J., Kuhs, K., Riederer, I., Sievert,
W., Hube, K., Mocikat, R., Dressel, R., Kremmer, E., Pockley, A. G., Friedrich, L., Vigh, L., Skerra, A., and Multhoff, G. (2011a). Targeting membrane heat-shock protein 70 (Hsp70) on tumors by cmHsp70.1 antibody. Proc. Natl. Acad. Sci. U.S.A. 108, 733-738.

Stangl, S., Themelis, G., Friedrich, L., Ntziachristos, V., Sarantopoulos, A., Molls, M., Skerra, A., and Multhoff, G. (2011b). Detection of irradiation-induced, membrane heat shock protein 70 (Hsp70) in mouse tumors using Hsp70 Fab fragment. Radiother. Oncol. 99, 313-316.

Steinman, R. M. (2007). Dendritic cells: understanding immunogenicity. Eur. J. Immunol. 37(Suppl. 1), S53-S60.

Stuart, L. M., Lucas, M., Simpson, C., Lamb, J., Savill, J., and LacyHulbert, A. (2002). Inhibitory effects of apoptotic cell ingestion upon endotoxin-driven myeloid dendritic cell maturation. J. Immunol. 168, 1627-1635.

Tang, D., Kang, R., Cheh, C. W., Livesey, K. M., Liang, X., Schapiro, N. E., Benschop, R., Sparvero, L. J., Amoscato, A. A., Tracey, K. J., Zeh, H. J., and Lotze, M. T. (2010a). HMGB1 release and redox regulates autophagy and apoptosis in cancer cells. Oncogene 29, 5299-5310.

Tang, D., Kang, R., Livesey, K. M., Cheh, C. W., Farkas, A., Loughran, P., Hoppe, G., Bianchi, M. E., Tracey, K. J., Zeh, H. J. III, and Lotze, M. T. (2010b). Endogenous HMGB1 regulates autophagy. J. Cell Biol. 190, 881-892.

Taylor, R. C., Cullen, S. P., and Martin, S. J. (2008). Apoptosis: controlled demolition at the cellular level. Nat. Rev. Mol. Cell Biol. 9, 231-241.

Torr, E. E., Gardner, D. H., Thomas, L., Goodall, D. M., Bielemeier, A., Willetts, R., Griffiths, H. R., Marshall, L. J., and Devitt, A. (2012). Apoptotic cell-derived ICAM-3 promotes both macrophage chemoattraction to and tethering of apoptotic cells. Cell Death Differ. 19, 671-679.

Truman, L. A., Ford, C. A., Pasikowska, M., Pound, J. D., Wilkinson, S. J., Dumitriu, I. E., Melville, L., Melrose, L. A., Ogden, C. A., Nibbs, R., Graham, G., Combadiere, C., and Gregory, C. D. (2008). CX3CL1/fractalkine is released from apoptotic lymphocytes to stimulate macrophage chemotaxis. Blood 112, 5026-5036.

Tsan, M. F., and Gao, B. (2009). Heat shock proteins and immune system. J. Leukoc. Biol. 85, 905-910.

Urbonaviciute, V., Furnrohr, B. G., Meister, S., Munoz, L., Heyder, P., 
De Marchis, F., Bianchi, M. E., Kirschning, C., Wagner, H., Manfredi, A. A., Kalden, J. R., Schett, G., Rovere-Querini, P., Herrmann, M., and Voll, R. E. (2008). Induction of inflammatory and immune responses by HMGB1-nucleosome complexes: implications for the pathogenesis of SLE. J. Exp. Med. 205, 3007-3018.

Vandenabeele, P., Galluzzi, L., Vanden Berghe, T., and Kroemer, G. (2010). Molecular mechanisms of necroptosis: an ordered cellular explosion. Nat. Rev. Mol. Cell Biol. 11, 700-714.

Vanlangenakker, N., Vanden Berghe, T., and Vandenabeele, P. (2012). Many stimuli pull the necrotic trigger, an overview. Cell Death Differ. 19, 75-86.

Voll, R. E., Herrmann, M., Roth, E. A., Stach, C., Kalden, J. R., and Girkontaite, I. (1997). Immunosuppressive effects of apoptotic cells. Nature 390, 350-351.

Wagner, B. J., Lindau, D., Ripper, D., Stierhof, Y. D., Glatzle, J., Witte, M., Beck, H., Keppeler, H., Lauber, K., Rammensee, H. G., and Konigsrainer, A. (2011). Phagocytosis of dying tumor cells by human peritoneal mesothelial cells. J. Cell Sci. 124, 1644-1654.

Wakatsuki, M., Ohno, T., Iwakawa, M., Ishikawa, H., Noda, S., Ohta, T., Kato, S., Tsujii, H., Imai, T., and Nakano, T. (2008). p73 protein expression correlates with radiation-induced apoptosis in the lack of p53 response to radiation therapy for cervical cancer. Int. J. Radiat. Oncol. Biol. Phys. 70 1189-1194.

Wu, Y., Singh, S., Georgescu, M. M., and Birge, R. B. (2005). A role for Mer tyrosine kinase in alphavbeta5 integrin-mediated phagocytosis of apoptotic cells. J. Cell Sci. 118 539-553.

Xiong, W., Chen, Y., Wang, H., Wu, H., Lu, Q., and Han, D. (2008). Gas6 and the Tyro 3 receptor tyrosine kinase subfamily regulate the phagocytic function of Sertoli cells. Reproduction 135, 77-87.

Xue, W., Zender, L., Miething, C. Dickins, R. A., Hernando, E. Krizhanovsky, V., Cordon-Cardo, C., and Lowe, S. W. (2007). Senescence and tumour clearance is triggered by $\mathrm{p} 53$ restoration in murine liver carcinomas. Nature 445, 656-660.

Youle, R. J., and Strasser, A. (2008). The BCL-2 protein family: opposing activities that mediate cell death. Nat. Rev. Mol. Cell Biol. 9, 47-59.

Zelenay, S., Keller, A. M., Whitney, P. G., Schraml, B. U., Deddouche, S., Rogers, N. C., Schulz, O., Sancho, D., and Reis, E. S. C. (2012). The dendritic cell receptor DNGR-1 controls endocytic handling of necrotic cell antigens to favor cross-priming of CTLs in virus-infected mice. J. Clin. Invest. 122, 1615-1627.

Zhang, J. G., Czabotar, P. E., Policheni, A. N., Caminschi, I., Wan, S. S. Kitsoulis, S., Tullett, K. M., Robin, A. Y., Brammananth, R., Van Delft, M. F., Lu, J., O'Reilly, L. A., Josefsson, E. C., Kile, B. T., Chin, W. J., Mintern, J. D., Olshina, M. A., Wong, W., Baum, J., Wright, M. D., Huang, D. C., Mohandas, N., Coppel, R. L., Colman, P. M., Nicola, N. A., Shortman, K., and Lahoud, M. H. (2012) The dendritic cell receptor Clec9A binds damaged cells via exposed actin filaments. Immunity 36, 646-657.
Conflict of Interest Statement: The authors declare that the research was conducted in the absence of any commercial or financial relationships that could be construed as a potential conflict of interest.

Received: 04 June 2012; paper pending published: 25 June 2012; accepted: 27 August 2012; published online: 11 September 2012

Citation: Lauber K, Ernst A, Orth M, Herrmann M and Belka C (2012) Dying cell clearance and its impact on the outcome of tumor radiotherapy. Front. Oncol. 2:116. doi: 10.3389/fonc.2012.00116

This article was submitted to Frontiers in Molecular and Cellular Oncology, a specialty of Frontiers in Oncology. Copyright (๑) 2012 Lauber, Ernst, Orth, Herrmann and Belka. This is an openaccess article distributed under the terms of the Creative Commons Attribution License, which permits use, distribution and reproduction in other forums, provided the original authors and source are credited and subject to any copyright notices concerning any third-party graphics etc. 